\title{
1. VARIATIONS IN EOLIAN AND CARBONATE SEDIMENTATION, SEA-SURFACE TEMPERATURE, AND PRODUCTIVITY OVER THE LAST 3 M.Y. AT SITE 958 OFF NORTHWEST AFRICA ${ }^{1}$
}

\author{
Uwe Pflaumann, ${ }^{2}$ Michael Sarnthein, ${ }^{2}$ Katherine Ficken, ${ }^{3}$ Alexandra Grothmann, ${ }^{2}$ and Amelie Winkler ${ }^{4}$
}

\begin{abstract}
Site 958 was drilled to monitor the late Neogene history of both continental aridity in northwestern Africa and the Canary Current distant from nearshore upwelling. Based on magnetostratigraphy, biostratigraphic datums, variations in carbonate, coarse fraction components, and the species composition of planktonic foraminifers, as well as using the $\delta^{18} \mathrm{O}$ records of Globigerinoides ruber (white), we established a splice between Holes 958A and 958B and a stratigraphic age scale deciphering Milankovitch cycles. Over the last 630 k.y., sedimentation rates amount to $2.9 \mathrm{~cm} / \mathrm{k} . \mathrm{y}$., and to $2.05-2.53 \mathrm{~cm} / \mathrm{k}$.y. back to the base of the Pleistocene. Extremely low rates of $0.4 \mathrm{~cm} / \mathrm{k} . \mathrm{y}$. and a reworking of fossils mark the late Pliocene.

The first continuous, long, sea-surface temperature (SST) record from the center of the Canary Current, which is based on foraminifer species census data, depicts a general temperature decrease in the late Pliocene, lower SST and high seasonalities of up to $6^{\circ} \mathrm{C} \sim 2.0-1.6 \mathrm{Ma}$, a warmer interval from 1.6 Ma to $\sim 0.85 \mathrm{Ma}$, again lower SST and higher seasonalities until 0.33 or $0.26 \mathrm{Ma}$, and a final warmer interval, lasting until at least $50 \mathrm{ka}$, possibly reflecting the attenuated dynamics of the Canary Current. Especially over the last 400 k.y., since Stage 11, glacial stages are hardly reflected by cold SST cycles, except for various abrupt and extremely short cooling events amounting to $\Delta 6^{\circ} \mathrm{C}$, which possibly result from North Atlantic Heinrich events. Similar, but not necessarily synchronous, events of short-term, extremely high values occur in the paleoproductivity and $\left(\delta^{13} \mathrm{C}-\right.$ based) paleonutrient records, which indicate a generally low primary production averaging to $180 \mathrm{~g} \mathrm{C} \mathrm{m}^{-2} \mathrm{yr}^{-1}$ at $50-330 \mathrm{ka}^{-}$ and about $300 \mathrm{~g} \mathrm{C} \mathrm{m}^{-2} \mathrm{yr}^{-1}$ back to the base of the Pleistocene. Near 1.2-1.6 Ma, the grain-size and magnetic susceptibility records document a significant increase in the discharge of south Saharan/Sahelian dust, possibly linked to increasing aridity.
\end{abstract}

\section{INTRODUCTION}

Ocean Drilling Program (ODP) Site $958 \quad\left(23^{\circ} 59.4^{\prime} \mathrm{N}\right.$; $20^{\circ} 00.05^{\prime} \mathrm{W} ; 3795 \mathrm{~m}$ water depth) was drilled as a "site of opportunity" to obtain a largely continuous hemipelagic sediment record of the late Neogene. Special targets were (1) to reconstruct the Pleistocene temperature and productivity history of the Canary Current outside the centers of coastal upwelling and complementary to the records of ODP neighboring Sites 658 and 659, and (2) to measure the variations in eolian dust discharge from the Saharan desert to monitor oscillations of continental aridity and wind regimes as linked to global climatic change. Closing a major gap, Site 958 completes a largescale paleoenvironmental transect (Fig. 1) of great value, spanning $30^{\circ}$ of latitude and linking up ODP Site 397 near $27^{\circ} \mathrm{N}$ off the Northern Sahara (Stein and Sarnthein, 1984) down to ODP Sites 658 and 659 near $18^{\circ}-21^{\circ} \mathrm{N}$ and Sites 660-663 near the equator (Ruddiman et al., 1988, 1989; Ruddiman, Sarnthein, et al, 1989; Tiedemann et al., 1989; Tiedemann et al., 1994).

Based on the initial core description (Firth et al., 1996), Site 958 revealed continuous but low average sedimentation rates of $2.3 \mathrm{~cm} /$ k.y. over the last 840 k.y. and $1.3 \mathrm{~cm} / \mathrm{k} . \mathrm{y}$. during the late Pliocene and early Pleistocene. These rates, however, appear sufficient to establish a simple paleoclimatic record with Milankovitch range cycles that can be correlated with the high-resolution records of various neighboring sites, especially that of Site 659 .

${ }^{1}$ Firth, J.V. (Ed.), 1998. Proc. ODP, Sci. Results, 159T: College Station, TX (Ocean Drilling Program).

${ }^{2}$ Geologisch-Paläontologisches Institut, Universität Kiel, Olshausenstr. 40, D24098 Kiel, Federal Republic of Germany. up@ gpi.uni-kiel.de

${ }^{3}$ Biogeochemistry Center, Department of Geology, University of Bristol, Queens Rd., Bristol BS8 1R5, United Kingdom.

${ }^{4}$ Geomar, Forschungszentrum für Marine Geowissenschaften der Universität Kiel, D-24148 Kiel, Federal Republic of Germany.

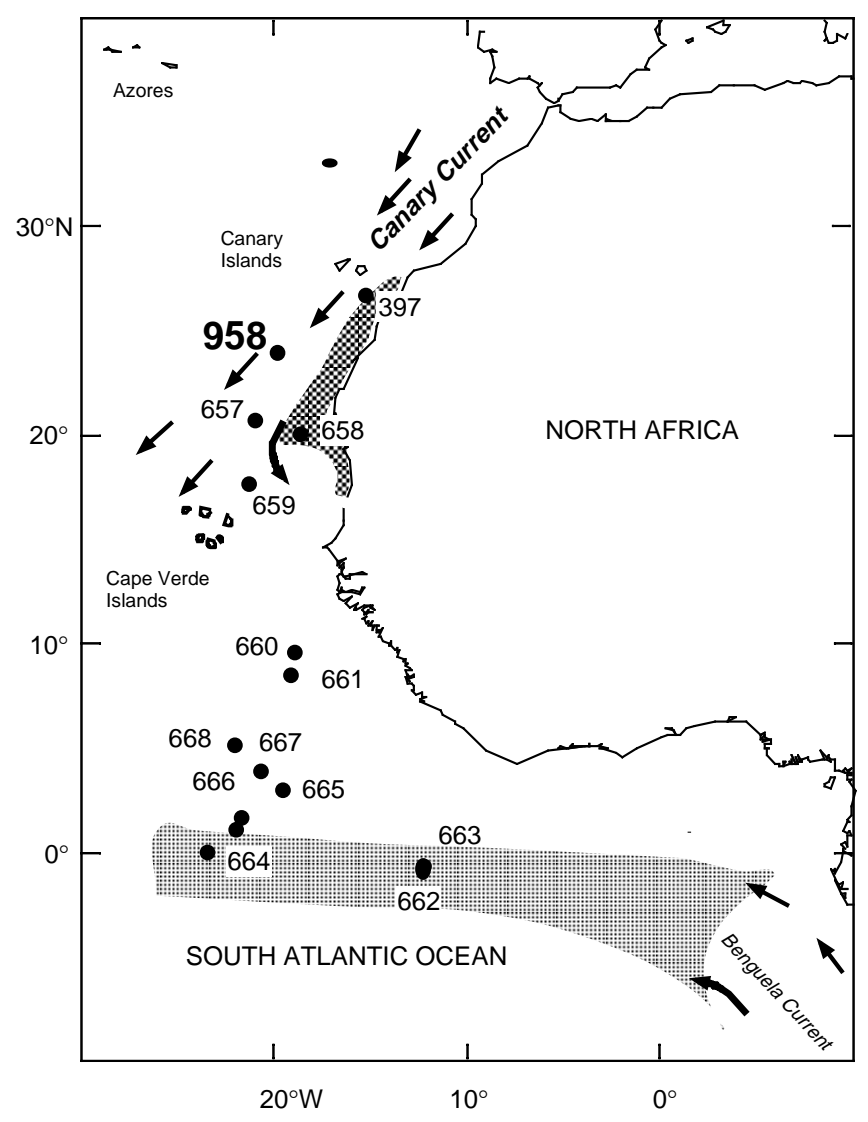

Figure 1. Location of ODP Site 958 and ODP site transect off West Africa. Ocean upwelling regions are stippled. Arrows mark surface currents. 
Major technical objectives of this report are to establish a composite depth section of the two sediment profiles in Holes 958A and $958 \mathrm{~B}$ and a rough age scale of the composite depth section with a time resolution of Milankovitch cycles based on correlations to stratigraphies from both $\mathrm{CaCO}_{3}$ concentrations and a preliminary planktonic $\delta^{18} \mathrm{O}$ record. The history of sea-surface temperatures (SST) is reconstructed by means of both $\mathrm{U}^{\mathrm{k}}{ }_{37}$ biomarkers and planktonic foraminifer species census data, which are also employed to reconstruct a local paleoproductivity record. Paleoproductivity values are compared with the planktonic $\delta^{13} \mathrm{C}$ record of nutrient concentrations near the surface of the Canary Current. Variations in continental aridity and eolian input are deduced from the magnetic susceptibility record, the sediment proportions of noncarbonate, siliciclastic grain sizes, and ratios of clay minerals. Variations in the degree of foraminifer fragmentation and grain sizes of the bulk sample indicate variations in $\mathrm{CaCO}_{3}$ dissolution near $3800 \mathrm{~m}$ water depth.

\section{METHODS}

A fairly narrow sample spacing $(8-10 \mathrm{~cm}$ in average, equal to $\sim 3$ k.y. over the last $600 \mathrm{k} . \mathrm{y}$. and >5-20 k.y. further back) was accomplished in Cores $159-958 \mathrm{~A}-1 \mathrm{H}$ through $6 \mathrm{H}$ and $159-958 \mathrm{~B}-1 \mathrm{H}$ by a sample-sharing plan between co-investigators of this report. Samples of generally $10-\mathrm{cm}^{3}$ and, in some cases, $20-\mathrm{cm}^{3}$ volume were shipped in cooled Igloo containers. Of each sample, $1 \mathrm{~cm}^{3}$ was used for analyses of $\mathrm{CaCO}_{3}$ (at a LECO CS125 instrument at Geomar, Kiel, and a COULOMAT 702 at the Geologisch-Paläontologisches Institut of Kiel University) and $\mathrm{U}^{\mathrm{k}}{ }_{37}$ (in Bristol; according to Rosell-Melé et al., 1995). Additional $\mathrm{CaCO}_{3}$ percentages were obtained from Firth et al. (1996). Samples of $8 \mathrm{~cm}^{3}$ were freeze-dried, weighed, and washed over a $63-\mu \mathrm{m}$ sieve.

The fraction $<63 \mu \mathrm{m}$ was retained wet and treated with acetic acid and subject to analyses of both grain sizes of the carbonate-free fraction in a SediGraph 5100 (Micromeritics) and clay minerals by X-ray (according to Biscaye, 1965; Chamley, 1989; Lange, 1982). The precision of the grain-size data reaches \pm 0.15 phi grades. The coarse fraction $>63 \mu \mathrm{m}$ was dried at $50^{\circ} \mathrm{C}$, weighed, and dry-sieved into size fractions finer and coarser than $150 \mu \mathrm{m}$. The latter fraction was weighed and used for (1) coarse-fraction modal analysis, (2) planktonic foraminifer counts, applying the standard techniques of CLIMAP (Kipp, 1976; modified by Pflaumann et al., 1996), and (3) stable-isotope analysis, using Globigerinoides ruber (white) (315-400 $\mu \mathrm{m})$ following Ganssen (1981). Concentrations of total organic carbon (TOC) were measured on a minor portion of (bulk) samples by means of a LECO CS125 analyzer at Geomar, Kiel, by the difference between total and carbonate carbon ( $\pm 2 \%$ standard deviation). The standard deviation of TOC values amounts to $\pm 5 \%$ of the measured (small) values.

Sea-surface temperatures for winter and summer were deduced from both a $\mathrm{U}_{37}^{\mathrm{k}}$ record and planktonic foraminifer species counts in the $150-\mu \mathrm{m}$ grain-size fraction using the SIMMAX modern analog technique of Pflaumann et al. (1996; modified equation version 28). Standard deviations of the difference between observed and estimated values lie within the range of $\pm 0.9^{\circ} \mathrm{C}(1 \sigma)$. The same counts served for deducing paleoproductivity estimates of the surface water, employing the modern satellite-based primary production patterns of Sathyendranath et al. (1995) as calibration base (Pflaumann et al., unpubl. data; Mix, 1989). $\mathrm{Uk}_{37}$ data were measured according to standard analytical procedures at the Organic Geochemistry Unit of Bristol University (Rosell-Melé et al., 1995).

Stable isotope values were measured on 15-20 specimens of $G$. ruber (white) from the $315-400-\mu \mathrm{m}$ size fraction. Prior to isotope analysis, the foraminifer tests were cracked open to release potential sediment fillings, and ultrasonically cleaned in ethanol, following the procedures outlined in Ganssen (1981) and Wang et al. (1995). Stable isotope data were determined with a FINNIGAN MAT 251 mass spectrometer linked online to an automated CARBO KIEL carbonate preparation line at the Leibniz Laboratory of Kiel University. Longterm reproducibility was $0.08 \%$ for $\delta^{18} \mathrm{O}$ and $0.05 \%$ for $\delta^{13} \mathrm{C}$ as calculated from replicate analyses of an internal carbonate standard (Solnhofen Limestone) that was routinely run at a 10-sample interval. The isotope data are referred to the Peedee belemnite (PDB) scale.

\section{RESULTS Carbonate Contents}

Carbonate concentrations generally vary between $40 \%$ and $90 \%$, with short-lasting, rare excursions down to $22 \%$ within the top 30 mbsf and up to $100 \%$ below 43 mbsf in Hole 958A (equal to $50 \mathrm{~m}$ composite depth [mcd]; see below; Fig. 2A). Concentrations of organic carbon generally range from $0.1 \%$ to $0.3 \%$, with rare excursions reaching as much as $0.6 \%$ to $1.3 \%$ (Fig. $2 \mathrm{~B}$ ) in samples obtained near various small, distal turbiditic sand layers (unpubl. core descriptions of Shore-based Scientific Party).

Based on the carbonate content, five stratigraphic intervals are distinguished (Fig. 2A):

1. The top 6-m sediment section in Hole 958B, which shows values varying between $40 \%$ and $75 \%$;

2. The top $11 \mathrm{~m}$ of Hole 958A (i.e., 6.4-17.4 mcd), which show $\mathrm{CaCO}_{3}$ values ranging between $60 \%$ and $90 \%$, with rare extremely low values reaching down to $22 \%$;

3. A 19-m interval with ongoing extreme oscillations between $22 \%$ and $85 \%$ marking the section between 11 and $30 \mathrm{mbsf}$ (17.4-36.4 mcd) in Hole 958A, whose lower boundaries correspond to the base of sedimentary Unit $1 \mathrm{~A}$ as defined by Firth et al. (1996);

4. A 14-m interval with extremely short-wavelength oscillations between $55 \%$ and $85 \%$, which occurs from 30 to about 44 mbsf (36.4-50.4 mcd); and

5. A 3-m interval with short-lasting oscillations between $70 \%$ and $100 \%$, which characterize the section at $44-47 \mathrm{mbsf}$ (50.4-53.4 mcd).

\section{Grain Sizes}

The long-term variations in percentage of coarse fraction $>63 \mu \mathrm{m}$ (Fig. 2C) show three similar stratigraphic intervals in the top 20-35 mcd as the carbonate curve (Fig. $2 \mathrm{~A}$ ), with increased values of $10 \%-$ $30 \%$ in the topmost 6 mbsf in Hole 958B (carbonate stratigraphy Interval 1), low values of $5 \%-20 \%$ in the top $11 \mathrm{~m}$ of Hole $958 \mathrm{~A}$ (carbonate stratigraphy Interval 2), and continuously marked fluctuations around 5\%-20\% from 11-47 mbsf (i.e., continuing through carbonate stratigraphy Intervals 3-5). Some rare, narrow fluctuations reach up to $50 \%$, representing distal turbidites (Table 1; Fig. 2C; Shorebased Party, unpubl. data).

Contrary to previous findings at the east Atlantic continental margin (e.g., Cita and Spezzibottiani, 1979), neither long- nor short-term fluctuations of coarse-fraction values run parallel to changes in carbonate concentration.

\section{Stable Isotope Records}

The poorly resolved $\delta^{18} \mathrm{O}$ record of G. ruber (white) in Figure 2D coarsely depicts the succession of isotope Stages 3.3-16 at 0-7 mbsf in Hole 958B and 0-11 mbsf in Hole 958A ( 17 mcd) as compared to the well-defined $\delta^{18} \mathrm{O}$ record at ODP Site 659 (Tiedemann et al., 1994). Our stage assignments are largely based on the close correlation of the highly resolved $\mathrm{CaCO}_{3}$ oscillations between Sites 958 and 659 (Fig. 3). The $\delta^{18} \mathrm{O}$ correlation is less distinct with Stages 


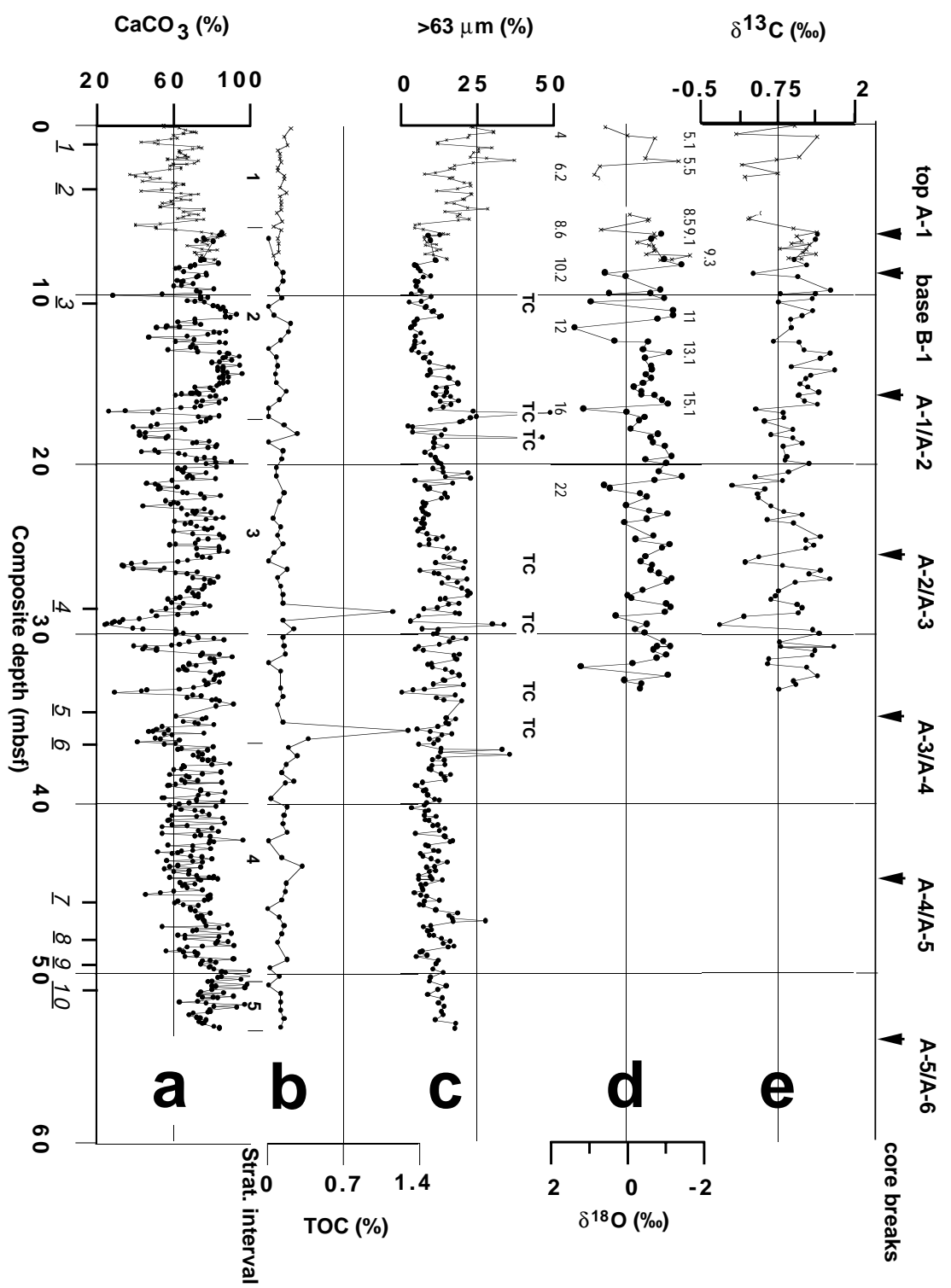

Figure 2. A. Percent $\mathrm{CaCO}_{3}$ in ODP Holes 958A (solid circles) and 958B (crosses), showing the splice between the two holes. Underlined numbers along the composite depth scale are calcareous nannoplankton and planktonic foraminifer datums: $1=\mathrm{LAD}$ G. hexagonus; $2=\mathrm{FAD}$ Emiliania huxleyi; 3 = LAD Pseudoemiliania lacunosa $; 4$ $=$ LAD Reticulofenestra asanoi; $5=\mathrm{LAD}$ H. sellii; $6=$ LAD C. macintyrei; $7=\mathrm{LO}$ of reworked $G$. miocenica; 8 $=$ FAD G. truncatulinoides $; 9=$ LAD G. miocenica $a$ and LAD G. puncticulata; 10 = LAD Discoaster pentaradiatus, Discoaster surculus, D. tamalis. Carbonate stratigraphic Intervals 1-5 are marked. B. Percent of organic carbon at Site 958, spliced. C. Percent coarse fraction $>63$ $\mu \mathrm{m}$ (spliced). TC $=$ turbidite layers (Table 1). D. Variations in parts per thousand $\delta^{18} \mathrm{O}(\mathrm{PDB})$ of the planktonic foraminifer Globigerinoides ruber (var. white) at Site 958, spliced. E. Variations in parts per thousand $\delta^{13} \mathrm{C}(\mathrm{PDB})$ of the planktonic foraminifer Globigerinoides ruber (var. white) at Site 958, spliced.
Table 1. Nominal depths (mbsf) and thickness of turbidite layers in ODP Hole 958A (Shore-based Party, unpubl. data)

\begin{tabular}{|c|c|c|c|c|}
\hline \multirow[b]{2}{*}{$\begin{array}{l}\text { Core, section, } \\
\text { interval }(\mathrm{cm})\end{array}$} & \multicolumn{2}{|c|}{$\begin{array}{l}\text { Depth } \\
\text { (mbsf) }\end{array}$} & \multicolumn{2}{|c|}{$\begin{array}{c}\text { Composite depth } \\
\text { (mbsf) }\end{array}$} \\
\hline & Top & Base & Top & Base \\
\hline 159-958A- & & & & \\
\hline $\begin{array}{l}1 \mathrm{H}-3,56-72 \\
\end{array}$ & $\begin{array}{r}3.56 \\
1049\end{array}$ & $\begin{array}{r}3.72 \\
1078\end{array}$ & $\begin{array}{r}9.93 \\
16.86\end{array}$ & 10.09 \\
\hline $2 \mathrm{H}-1,41-55$ & 11.41 & $\begin{array}{l}11.55 \\
11.55\end{array}$ & $\begin{array}{l}10.00 \\
17.78\end{array}$ & 17.87 \\
\hline $2 \mathrm{H}-2,83-107$ & 11.83 & 12.07 & 18.20 & 18.44 \\
\hline $3 \mathrm{H}-1,42-70$ & 19.42 & 19.70 & 25.79 & 26.07 \\
\hline $3 \mathrm{H}-3,23-34$ & 22.23 & 22.3 & 28.6 & \\
\hline $3 \mathrm{H}-3,68-121$ & 22.68 & 23.21 & 29.05 & 29.58 \\
\hline $3 \mathrm{H}-6,45-76$ & 26.95 & 27.26 & 33.32 & 33.63 \\
\hline $4 \mathrm{H}-1,56-105$ & 29.06 & 29.55 & 35.43 & 35.92 \\
\hline
\end{tabular}

17-22, down to 15 mbsf in Hole 958A (about $21.5 \mathrm{mcd}$; Fig. 2D). No correlation is possible farther downcore.

The $\delta^{13} \mathrm{C}$ record of G. ruber (white) (Fig. 2E; i.e., a record of the nutrient concentration in the surface water; Sarnthein and Winn, 1990) shows $0 \%{ }^{\circ}-0.8 \%$ in the top $6 \mathrm{mbsf}$, in carbonate stratigraphic
Interval 1. Farther below, in carbonate stratigraphic Interval 2, the $\delta^{13} \mathrm{C}$ values cover a fairly constant range of $0.7 \%$ - $1.7 \%$, corresponding to a low nutrient level. In carbonate stratigraphic Interval 3 a few pronounced $\delta^{13} \mathrm{C}$ minima ( $0 \%$ or less; i.e., nutrient maxima) match extreme carbonate lows (Fig. 2A) at 8.75, 16.8, 21.3, 25.8, and 29.5 mcd.

\section{Composition of the Coarse Fraction}

As shown in Figure 4A, fairly constant small percentages $(0.2 \%-$ $0.5 \%$ ) of echinoderm, molluscan, and especially pteropod fragments occur between 0 and 31 mcd. Farther below, major sections in Hole 958A are devoid of any molluscan and echinoderm debris except for several discrete stratigraphic levels. Likewise, most samples are barren of radiolarians throughout the section (Fig. 4B). Nevertheless, up to $15 \%$ radiolarian tests occur in rare and narrow core intervals (at $2.85,5.85,8.3,18.38$, and $35.78 \mathrm{mcd}$ ), close to major abundance maxima of Neogloboquadrina pachyderma (sinistral [s]) (Figs. 5, 6), which is indicative of exceptionally low SSTs (Bé and Tolderlund, 1971) in cold isotopic (Sub-) Stages 6.4, 8.4, 10, 18.4, and near 1.6 Ma (stages as defined in Fig. 3; see below). 
Figure 3. Tentative correlation of variations in percent $\mathrm{CaCO}_{3}$ in Holes 958A (solid circles) and 958B (open circles) (spliced) to the age-calibrated carbonate record of neighbor Site 659 (Tiedemann, 1991). Average sedimentation rates across carbonate stratigraphic Intervals $1-3$, main isotope stages, and rare magnetic polarity data (Firth et al., 1996) are indicated.

Nonbiogenic and lumped grains are largely absent in the coarse fraction (Fig. 4C), except for a few extreme values reaching up to $17 \%$, which mostly represent the nine, 9 - to $53-\mathrm{cm}$-thick turbidite layers described by the Shore-based Party (Table 1; Fig. 2C). Benthic foraminifers generally comprise $<3 \%$ (Fig. 4D). Rare maxima of $4 \%-11.5 \%$ occur at $11.9,17.0,17.85,29.5,35.85$, and $40.3 \mathrm{mcd}$, depths that are mostly linked to the turbidite layers (Table 1).

Fragments of planktonic foraminifers amount to $\sim 7 \%-25 \%$ of the sand fraction in the top $6 \mathrm{mbsf}$ and to $20 \%-50 \%$ farther below (Fig. $4 \mathrm{E})$. Here, a lower level of fragmentation rates unexpectedly correlates to generally lower percent $\mathrm{CaCO}_{3}$ values and vice versa (Fig. $2 \mathrm{~A})$. In the short-term fluctuations, however, the high fragmentation values generally match reduced $\mathrm{CaCO}_{3}$ values and/or the onset of percent $\mathrm{CaCO}_{3}$ minima, and hence indicate an increased dissolution during most cold (sub-) stages such as (Sub-) Stages 4, 6.4, 7.4, 8.4, 10, 11.2 (?), 12.2, 20, and 22 (Fig. 3; see below). In two samples near 36.5 and $37.0 \mathrm{mcd}$, which may also belong to turbidites (Fig. 2C), the foraminifer fragmentation amounts to $100 \%$-without any link to potential $\mathrm{CaCO}_{3}$ minima, however.

\section{Distribution of Planktonic Foraminifers}

The group of cool and cold-water species (Neogloboquadrina pachyderma [s] and [dextral (d)], T. quinqueloba) generally ranges between $5 \%-10 \%$ and $60 \%$ of the planktonic foraminifer assemblage (Fig. 5; Bé and Tolderlund, 1971; Pflaumann et al., 1996). Their maxima occur near $6.0-6.5,11.5-13.5,17-18.5,29-30,35.5-41$, and 42.5-48.5 mcd and are generally linked to carbonate minima (Fig. $2 \mathrm{~A}$ ), with fairly low values dominating at $0-5 \mathrm{mcd}$ and between 25 and $35 \mathrm{mcd}$. The group of temperate and coastal-upwelling species is dominated by Globigerina bulloides, Globorotalia inflata and truncatulinoides, and the G. crassaformis group, and by the Pliocene species Globorotalia puncticulata below $49.5 \mathrm{mcd}$. This group shows fairly persistent concentrations of $20 \%$ to $50 \%$, with lower propor- 


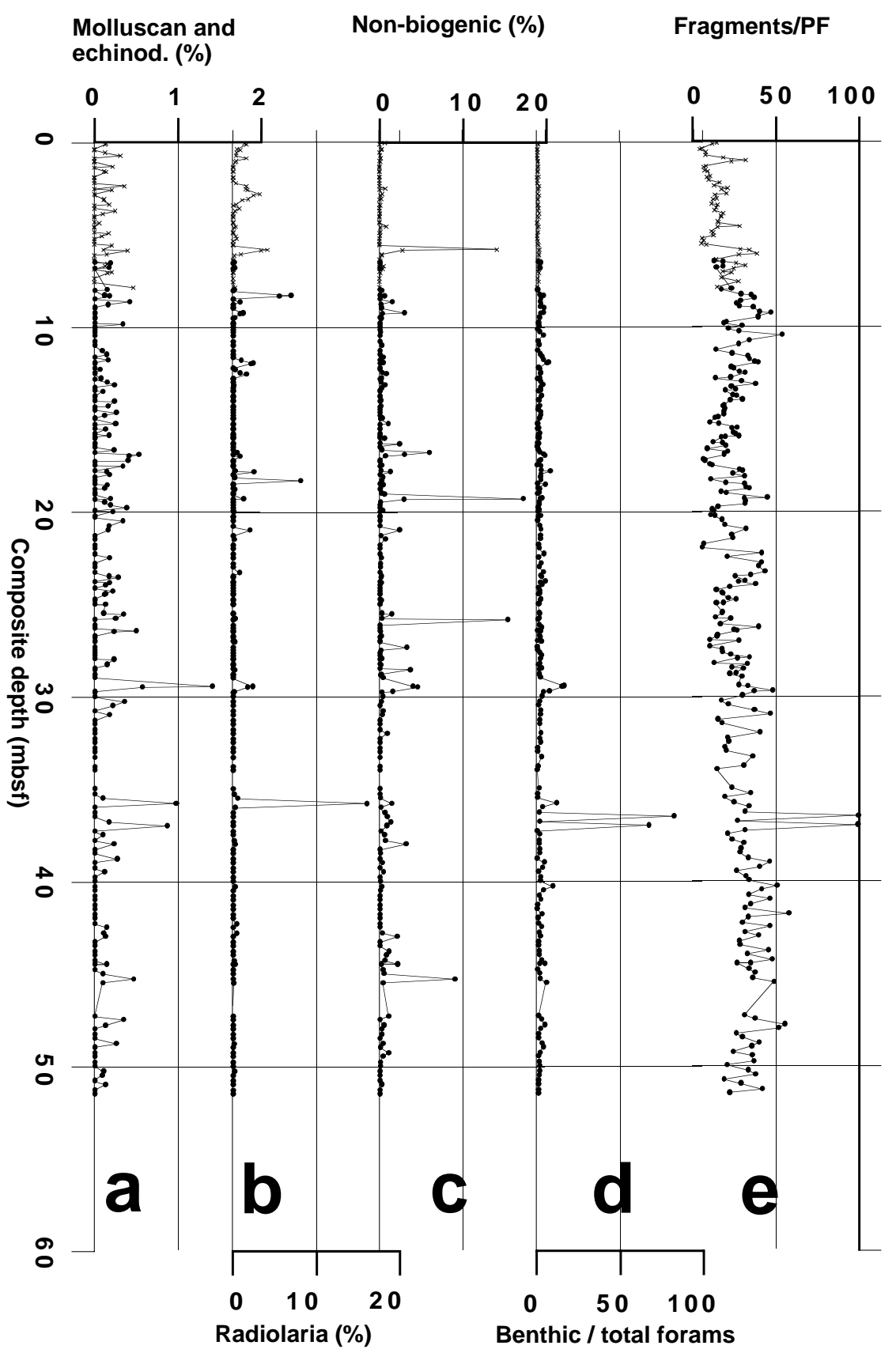

Figure 4. Coarse fraction composition at Site 958. Curves of Holes 958A (solid circles) and 958B (crosses) are spliced. A. Percent molluscan and echinoderm fragments. B. Percent radiolarians. C. Percent nonbiogenic grains. D. Percent benthic foraminifers of total foraminifers. E. Percent fragments of total planktonic foraminifers $(\mathrm{PF})$. tions between 11 and $20 \mathrm{mcd}$ and in the lower part of the section. The concentrations of the tropical-subtropical assemblage (Globigerinoides trilobus, G. ruber, Pulleniatina obliquiloculata, Globorotalia menardii/tumida, Globorotaloides hexagonus, Neogloboquadrina dutertrei) are highly variable, oscillating between $5 \%$ and $30 \%$ in the top $20 \mathrm{mcd}$, with short-lasting extreme spikes near $11 \mathrm{mcd}$ and especially below $16 \mathrm{mcd}$. This tropical and subtropical group shows a clear increase to $25 \%-45 \%$ below $20 \mathrm{mcd}$, which is about the top of the Matuyama Chron (Firth et al., 1996). Globigerinita glutinata has been separated from this grouping as a cosmopolitan species.

The Arctic species $N$. pachyderma (s) is largely absent from $0-8$ mcd (equal to the last nine stages; see below) and shows minor concentrations of $1 \%-4 \%$ farther below. However, higher concentrations of $10 \%-25 \%$ occur in some short intervals (Fig. 6A), which match the particularly cold events of isotope Stages 10, 16, 18, 20, 24 (as explained below) and various unidentified cold events in the core section down to $36 \mathrm{mcd}$ ( 1.6 Ma; see below).

The concentrations of the subpolar species N. pachyderma (d) cover a more uniform range of $15 \%$ to $40 \%$ (Fig. 6B). Rare maxima of $\sim 50 \%-72 \%$ parallel carbonate minima (Fig. $2 \mathrm{~A}$ ) assigned to isotope Stages 8 and 12 (see below). Below $28 \mathrm{mcd}$, there are various intervals that contain less than $10 \%$ of this species.

The concentrations of the temperate species G. inflata (Fig. 6C) oscillate fairly uniformly on short-term cycles between $8 \% / 10 \%$ and $25 \% / 30 \%$, without any obvious correlation to the $\mathrm{CaCO}_{3}$ stratigraphic record (Fig. 2A). Reduced percentages of $G$. inflata occur in the upper Pliocene. On the other hand, G. bulloides (Fig. 6D), which is characteristic of coastal upwelling (Prell and Curry, 1981), shows a fairly constant background near $10 \%$ and a few prominent maxima reaching $20 \%-30 \%$, peaks that are linked to distinct carbonate mini- 


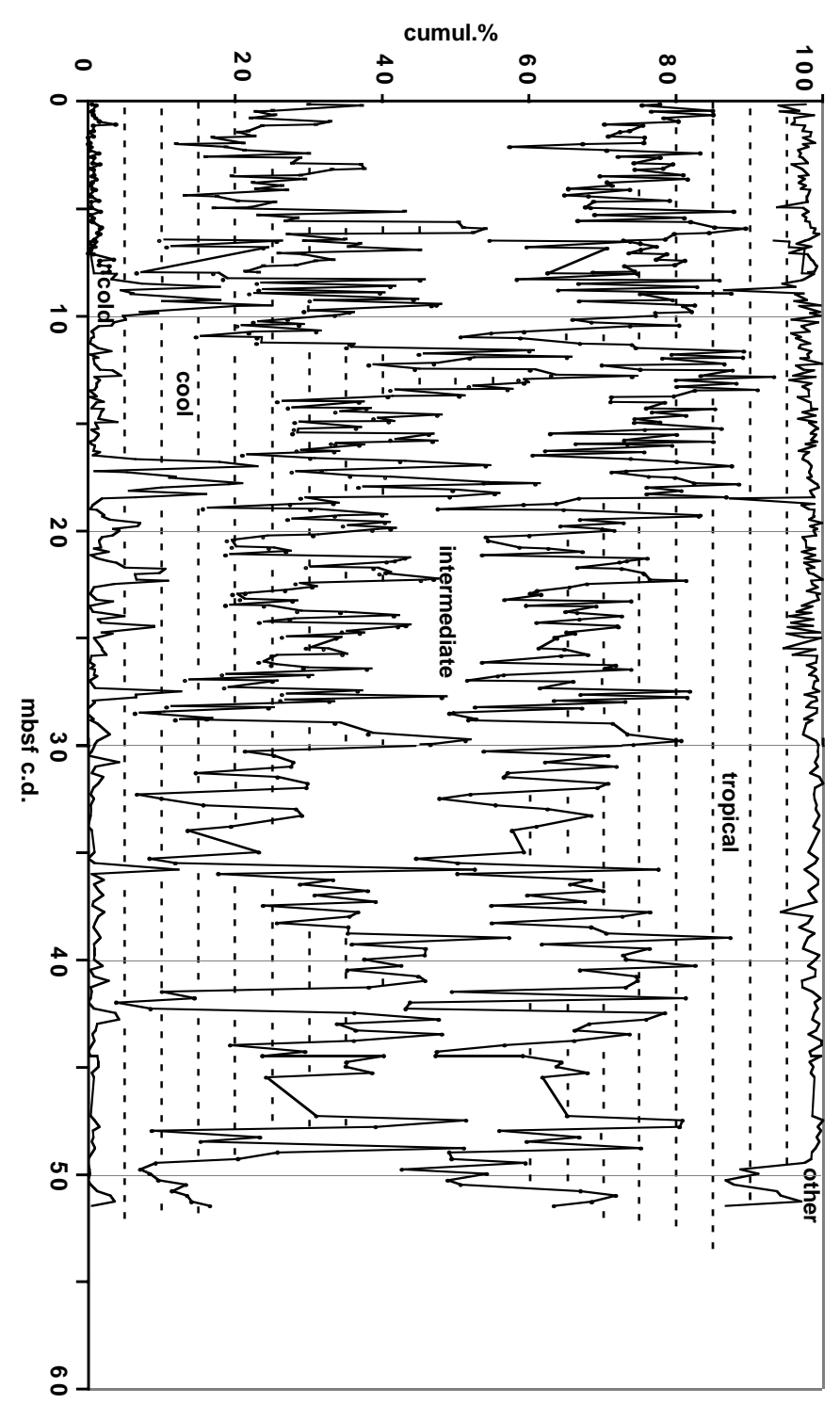

Figure 5. Cumulative percentages of major species groups of planktonic foraminifers, indicative of main ocean environments. Records of Holes 958A and $958 \mathrm{~B}$ are spliced.

ma (i.e., cold isotope stages; see below) in the topmost $20 \mathrm{mcd}$. Moreover, various small maxima occur in the lower part of the section, up to $51 \mathrm{mcd}$.

Among the warm-water species, $P$. obliquiloculata shows a clear maximum between 20 and $35 \mathrm{mcd}$, about 0.84-1.6 Ma (Firth et al., 1996). In the top $20 \mathrm{~m}$, it is largely absent (Fig. 6E). In contrast, $G$. ruber (pink) only occurs in the top $25 \mathrm{mcd}$, with short-lasting maxima of $3 \%-7 \%$ at $4.35,7.9,9.8,11.3,19.0$, and $23.2 \mathrm{mcd}$ (Fig. $6 \mathrm{~F}$ ) that match $\mathrm{CaCO}_{3}$ maxima in Fig. $2 \mathrm{~A}$ (interpreted as warm isotope stages; see below). The variations in percent G. ruber (white) (3\%-30\%; Fig. 6G) show similarities with both $P$. obliquiloculata in the lower section and G. ruber (pink) in the upper section of the profile studied. G. trilobus trilobus is generally rare $(0 \%-3 \%)$ but reaches $5 \%-7 \%$ (Fig. $6 \mathrm{H}$ ) along the outlined few warm intervals where $G$. ruber (pink) is enriched.
AGE CONTROL

\section{Composite Depth Section of ODP Site 958}

No exact correlation was established between Holes 958A and 958B by the initial shore-based studies of both the nannofossil and paleomagnetic records and the physical properties records (Firth et al., 1996). However, our new high-resolution $\mathrm{CaCO}_{3}$ records revealed a clear, simple core splice at $6.37 \mathrm{mbsf}$ in Hole 958B equal to 0 mbsf in Hole 958A (Fig. 2A). This is the only depth interval where the generally higher $\mathrm{CaCO}_{3}$ values $(73 \%-85 \%)$ in the top section of Core 159-958A-1H match equally high values in the lowermost part of Core 159-958B-1H. Farther upcore in Hole 958B, all $\mathrm{CaCO}_{3}$ values range below $\sim 75 \%$. This core splice is supported by the grain size curves (Fig. 2C), the $\delta^{18} \mathrm{O}$ and $\delta^{13} \mathrm{C}$ records (Fig. 2D and 2E), the planktonic foraminifer-based SST records (a little less accurately; Fig. 8), the set of curves of coarse-fraction abundance (Fig. 2C) and foraminifer species (Fig. 6), and finally, the general shift in magnetic susceptibility between Hole 958A and Hole 958B (Fig. 7, except for two outliers at the base of Hole 958B).

The meters composite depth leads to an overlap of undisturbed core sections between 6.37 and $7.94 \mathrm{mcd}$. We employed the core splice of 0 mbsf in Hole 958A equal to 6.37 mbsf in Hole 958B for constructing all proxy data records on the composite depth scale, as shown in Figures 2-9. Unfortunately, no double coring was available to bridge the various coring gaps farther downcore in Hole 958A (as indicated in Fig. 2).

\section{Tentative Chronostratigraphy and Sedimentation Rates}

The $\delta^{18} \mathrm{O}$ record of G. ruber (white) in Figure 2D is still insufficient for a precise definition of $\delta^{18} \mathrm{O}$ stages at Site 958 . Hence, we mainly rely for our chronostratigraphy on the $\mathrm{CaCO}_{3}$ curve of Holes 958A and 958B, which has narrow sample spacings (Fig. 2A) and provides a close similarity with the age-calibrated $\mathrm{CaCO}_{3}$ curve obtained from neighboring Site 659, drilled at $3070 \mathrm{~m}$ water depth (Tiedemann, 1991; Tiedemann et al., 1989). As demonstrated in Figure 3, similarities are common between the records from Sites 958 and 659 back to about $24 \mathrm{mcd}(=1 \mathrm{Ma})$, similarities that enable us to establish a tentative stratigraphy of stages analogous to stable isotope stages. No precise match of the $\mathrm{CaCO}_{3}$ fluctuations occurs farther downcore, where the sedimentation rates at Site 958 are increasingly low. Unfortunately, no continuous record of magnetic polarities is available for more accurate stratigraphic correlations (Firth et al., 1996).

The match between the age-calibrated $\mathrm{CaCO}_{3}$ curve of Site 659 and the curve of Site 958 reveals that the top of Core 159-958B-1H has an age of $\sim 45$ k.y., a little younger than oxygen isotope Substage 3.3 (Figs. 2A, 3). Farther below, the top of Substage 5.1 is confirmed by the last occurrence (LO) of Globorotaloides hexagonus in Core 159-958B-1H, 1.10 mbsf. The base of Core 159-958B-1H (7.9 mbsf) belongs to the end of Substage 9.3 and the top of Core 159-958A-1H $(6.37 \mathrm{mcd})$ to Substage 8.5 . These age-control points are corroborated by (1) the still coarsely resolved $\delta^{18} \mathrm{O}$ record (Fig. 2D), and (2) marked G. menardii spikes culminating at 2.27, 10.71, and 18.7-19.0 mcd (Fig. 6I), depths that correspond to the warm isotope (Sub-) Stages 5.5, 11.3 (end), and 19 (sensu Prell et al., 1986).

Further tentative age-depth correlations at Site 958 and the estimates of sedimentation rate are listed in Table 2. In the top $16.5 \mathrm{mcd}$ (Stage $16=635 \mathrm{ka}$ ), average sedimentation rates amount to $2.9 \mathrm{~cm} /$ k.y. Farther below, down to the LO of Helicosphaera sellii (1.47 Ma) at $34.58 \mathrm{mcd}$, they decrease to $2.05 \mathrm{~cm} / \mathrm{k}$.y. This change in sedimentation rates, which particularly comprises a loss of major parts of 


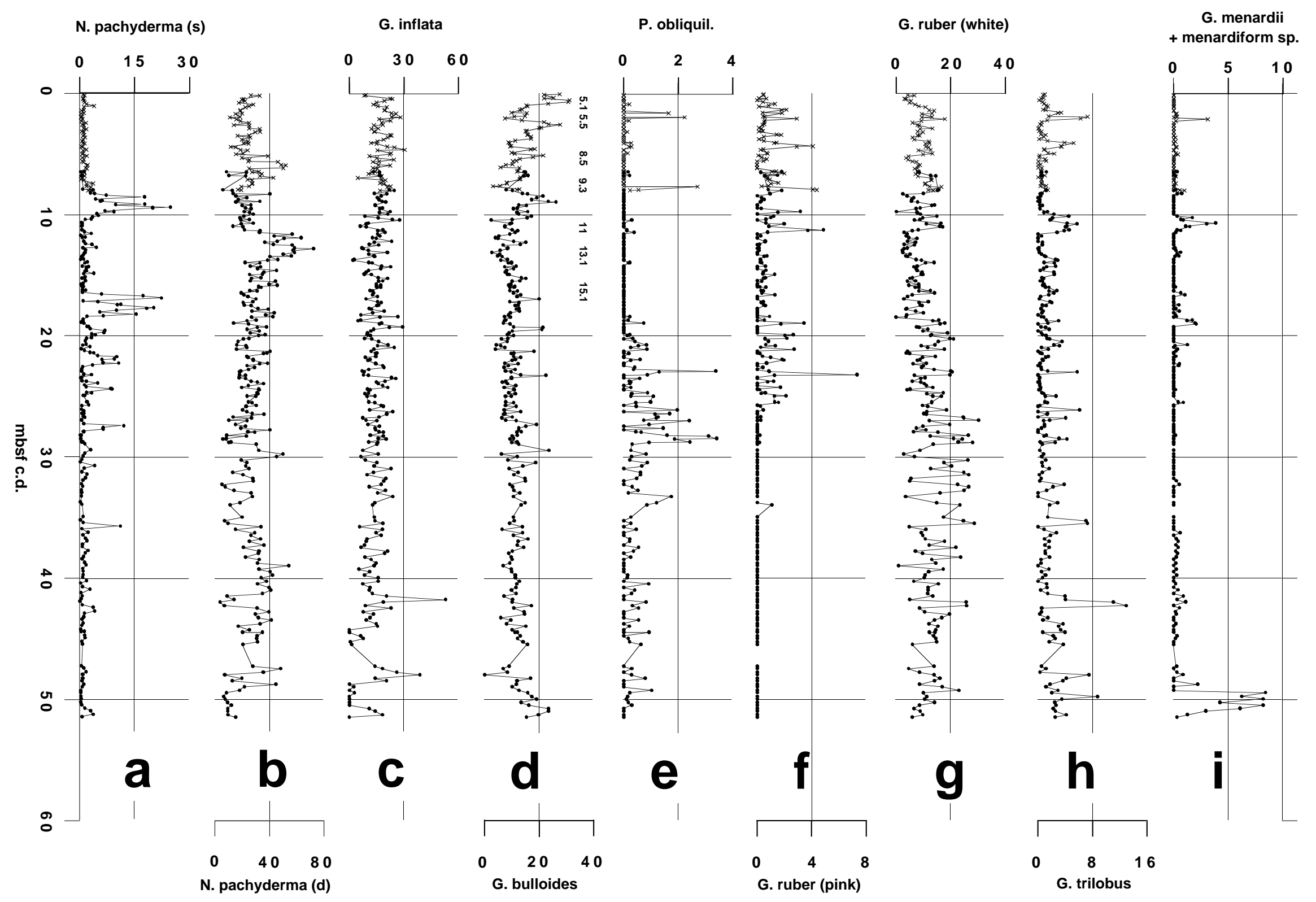




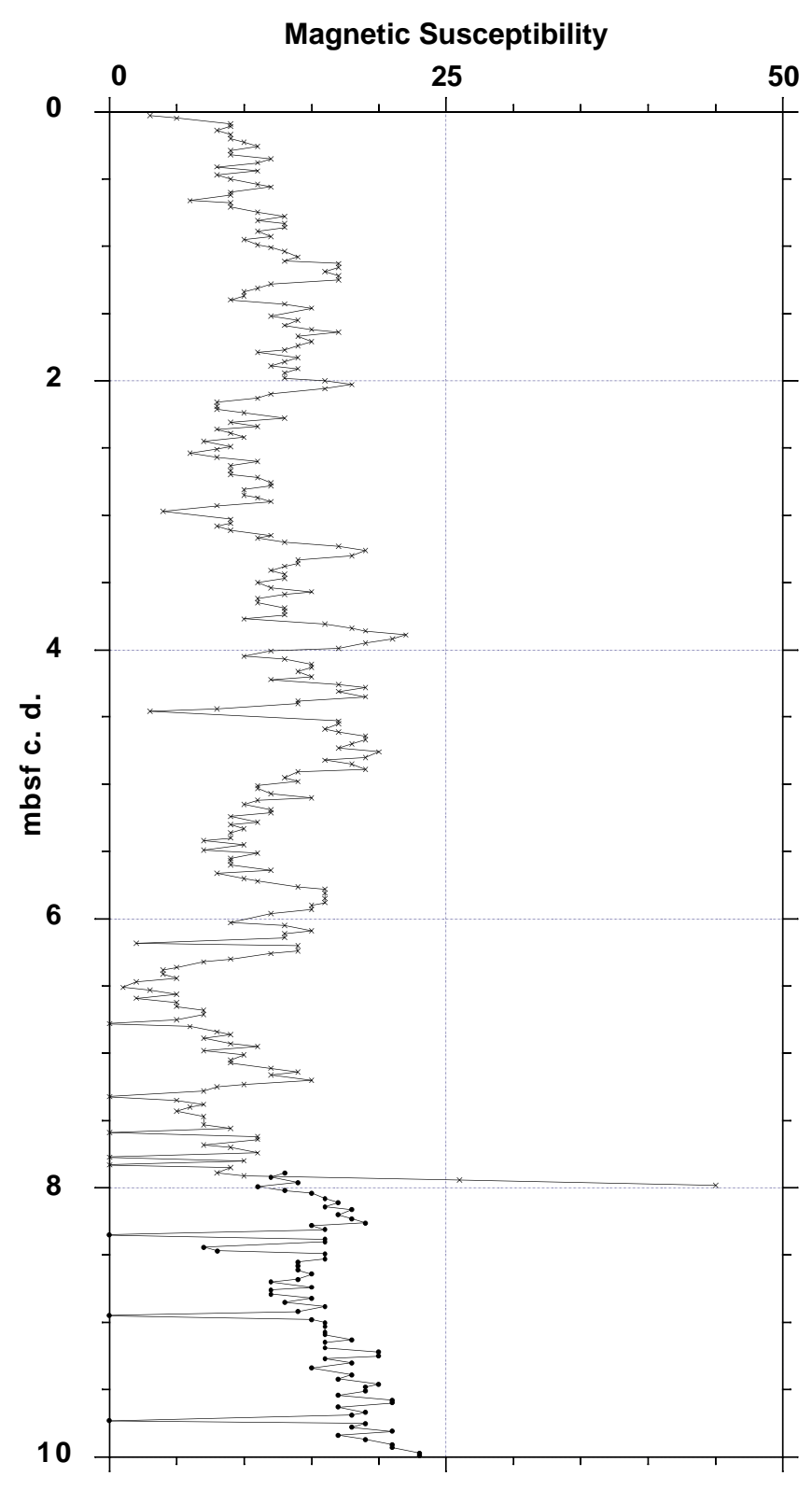

Figure 7. Volume magnetic susceptibility (SI) vs. composite depth (5-10 mbsf) from Holes 958A (solid circles) and 958B (crosses), showing the splice between the two holes.

Stage 16 , is not linked to any core break, but probably results from an erosion by minor turbidites (coarse fraction spikes in Fig. $2 \mathrm{C}$, near 16.86-17.15 and 18.2-18.44 mcd; Table 1). Our age definition of a "Stage 22" is corroborated by the negative (Matuyama) polarity found in three samples below 21.33 mcd (recalculated from Firth et al., 1996).

Below about $25 \mathrm{mcd}$, the age control is based on a positive (Olduvai) polarity found at $43.43 \mathrm{mcd}$ and the biostratigraphic datums reported by Firth et al. (1996), supplemented by the first occurrence (FO) of G. truncatulinoides (2.0 Ma) at $48.00 \mathrm{mcd}$ and the LO of $G$. miocenica (2.3 Ma) and Globorotalia puncticulata $(2.41 \mathrm{Ma})$ at 49.47 mcd (Fig. 2A; ages according to Berggren et al., 1995). Near this time, the warm-water menardiform species document an abrupt and pronounced change in water masses, decreasing from about $8 \%$ to some $1 \%-2 \%$ (Fig. 5I).

Sedimentation rates average $2.53 \mathrm{~cm} / \mathrm{k}$.y. between the LO of Helicosphaera sellii and the FO of $G$. truncatulinoides and fall to a minimum of $0.39 \mathrm{~cm} / \mathrm{k} . \mathrm{y}$. between the FO of $G$. truncatulinoides and the LO of Discoaster tamalis (2.78 Ma) at 51.04 mcd (Fig. 2A). Farther below, down to the LO of Reticulofenestra umbilica (3.75 Ma) at $63.00 \mathrm{mcd}$, the rates again increase to $1.2 \mathrm{~cm} / \mathrm{k}$.y. The extremely low sedimentation rates at $48-51 \mathrm{mcd}$, between 2.0 and $2.78 \mathrm{Ma}$, indicate an 800-k.y.-long period of ongoing nonsedimentation or intermittent erosion not depicted in the core photographs (Firth et al., 1996). However, a maximum in coarse fraction near $47 \mathrm{mcd}$ and reworked lower Pliocene planktonic foraminifers such as Globorotalia miocenica and Dentoglobigerina altispira, which occur up to $45.77 \mathrm{mcd}$ immediately on top of the low-sedimentation-rate section, corroborate the model of a late Pliocene stratigraphic gap at Site 958.

\section{DISCUSSION}

\section{Evolution of SST in the Canary Current}

ODP Site 958 is located $380 \mathrm{~km}$ off the shore of Africa and thus, away from the coastal upwelling belt (Schemainda et al., 1975). Accordingly, we may expect that the SST curves at this site mainly record the general temperature history of the Canary Current. During warm stages of the Brunhes Chron (Fig. 2A; Stage 19), the variations in summer temperatures culminate near $23^{\circ} \mathrm{C}$ and winter temperatures near $18^{\circ} \mathrm{C}$ (Fig. 8). Near $28 \mathrm{mcd}, \sim 1.2-1.3 \mathrm{Ma}$, maximum summer and winter temperatures rise by $\sim 2^{\circ}-3^{\circ} \mathrm{C}$ and reach maxima of $25^{\circ}-27^{\circ} \mathrm{C}$ during summer and $21^{\circ}-24^{\circ} \mathrm{C}$ during winter between 28 and 35 mcd (LO Calcidiscus macintyrei; $\sim 1.6 \mathrm{Ma}$ ). In contrast, the SST range of the earliest Pleistocene and late Pliocene (below 35.5 mcd) is lower, with summer temperatures of $16^{\circ}-22^{\circ} \mathrm{C}$ or $25^{\circ} \mathrm{C}$ and largely matches that found during the Brunhes Chron. We cannot exclude that the lower SST prior to 1.6 Ma may be an artifact resulting from no-analog habitats of planktonic foraminifer species during this time.

Between 1 and $0.26 \mathrm{Ma}(\sim 23.0-5.5 \mathrm{mcd})$ and in the oldest Pleistocene (below $38 \mathrm{mcd}$ ), the seasonal temperature variations uniformly range between $4^{\circ} \mathrm{C}$ and $6.5^{\circ} \mathrm{C}$ (Fig. 8C). During the last 260 k.y. and the warmer period between 23 and $38 \mathrm{mcd}$, the seasonality range is generally reduced to about $3.5^{\circ}-5^{\circ} \mathrm{C}$ over broad intervals. Based on these data, we conclude that over the last $260 \mathrm{k} . \mathrm{y}$. and in the early Pleistocene $(\sim 1.2-1.6 \mathrm{Ma})$, the intensity of the forcing trade winds was markedly attenuated, especially during winter, and thus the dynamics of the Canary Current were reduced. The attenuation of the trade winds is documented by warmer winter temperatures (Fig. 8A) that resulted in the reduction of the SST seasonality.

Within the range of the Milankovitch cycles, the SST records at Site 958 barely reflect the generally observed long-term cooling during glacial stages (Crowley, 1981) during the Brunhes Chron, but rather show a uniformly warm SST plateau. On the other hand, this plateau is incised by numerous abrupt and extremely short cold excursions that amount to $\Delta 5^{\circ}-6^{\circ} \mathrm{C}$ and only match the extremes of the cold isotopic stages. These cold SST excursions as reconstructed from planktonic foraminifers appear real because they are clearly reproduced by the more widely spaced $\mathrm{U}^{\mathrm{k}}$ record of SST back to Stage 11 (Fig. 8D). Because of the low sampling resolution and poor age control, we cannot identify the actual origin of the SST excursions that may present a potential response to short-term Heinrich events in the North Atlantic (Bond and Lotti, 1995; Wang et al., 1995).

The actual position of the peak warm stages is only depicted by the occasional maxima of the highly SST-sensitive species $G$. ruber 


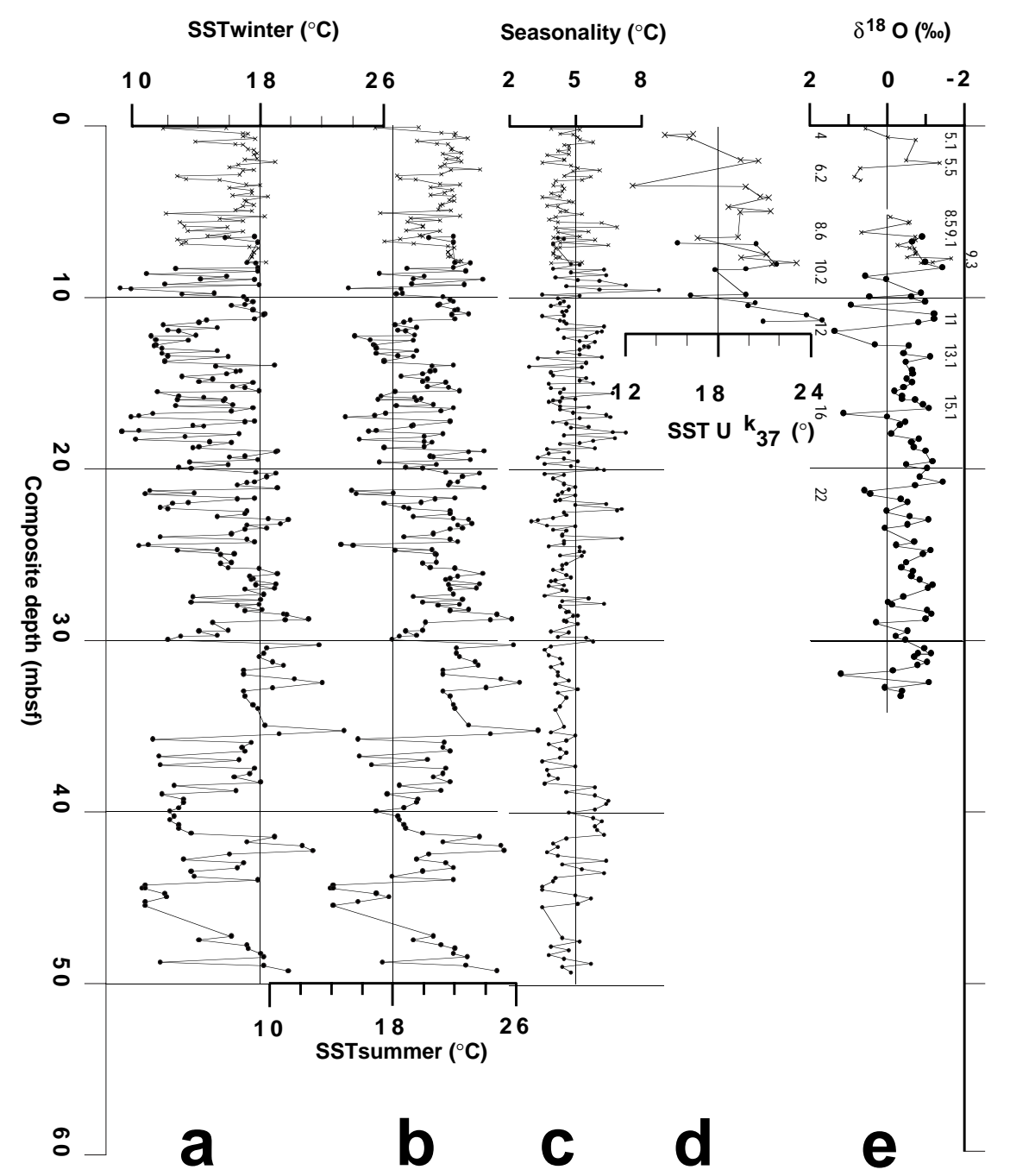

Figure 8. Variations in parts per thousand $\delta^{18} \mathrm{O}(\mathrm{PDB})$ (E) and estimated sea-surface temperature variations, (in ${ }^{\circ} \mathrm{C}$ ) in Holes 958A (solid circles) and 958B (crosses), spliced. Winter (A), summer temperature (B), and seasonality $(\mathbf{C})$ records are based on planktonic foraminifer counts (SIMMAX 28; Pflaumann et al., 1996). SST estimates (annual average) (D) are based on $\mathrm{U}^{\mathrm{k}}{ }_{37}$ biomarker analyses. (pink), which only appeared at Site 958 in the late Matuyama Chron (top 26 mcd in Fig. 6F).

\section{Evolution of Nutrients and Productivity in the Canary Current}

Based on counts of planktonic foraminifers, the base level of primary production in the Canary Current was continuously low, near $300 \mathrm{~g} \mathrm{C} \mathrm{m}^{-2} \mathrm{yr}^{-1}$ from 2.4-0.33 Ma (49 mcd; Fig. 9). Over the last 330 k.y. since Stage 9 (about $8 \mathrm{mcd}$ ), this base level was further reduced to $180 \mathrm{~g} \mathrm{C} \mathrm{m}^{-2} \mathrm{yr}^{-1}$. On top of it, however, we observe a small number of extreme productivity excursions, reaching up to $1100 \mathrm{~g} \mathrm{C} \mathrm{m}^{-2} \mathrm{yr}^{-1}$, which mainly derive from G. bulloides maxima (Fig. 6D). Based on our tentative age scheme, these spikes are linked to isotope Stage boundaries 3/4, 5/6, 7/8, 25/26, and to cold Stages 10, 14, and two older stages not identified.

Likewise, the generally high $\delta^{13} \mathrm{C}$ values of the surface dweller $G$. ruber (white) $(0.8 \%$ o $-1.7 \%$; Fig. 9B) indicate a predominantly low nutrient level in the surface water (Sarnthein and Winn, 1990; Jung, 1990). In addition, a number of $\delta^{13} \mathrm{C}$ lows of $-0.2 \%$ o to $0.5 \%$ o occur both in the poorly resolved core section at less than $6 \mathrm{mcd}$ and farther below, near 8.5, 21.3, 23.3, 25.5, and $29.0 \mathrm{mcd}-$ lows that indicate high nutrient concentrations and consistently match the rare paleo- productivity maxima depicted in Figure 9. The rare maxima in radiolarian tests (Fig. 4B), however, which also serve as potential tracers of high productivity, rarely match the ephemeral maxima of (bulk) primary productivity.

In theory, the prominent maxima in nutrients and paleoproductivity at Site 958 may be either linked to distal effects of West African coastal upwelling or upwelling productivity in the wake of the Canary Islands, or to the effect of iceberg-borne nutrient-enriched meltwater during various Heinrich events (Kiefer et al., 1995). Based on the present great offshore distance of $380 \mathrm{~km}$ from Africa (Fig. 1), which has been little reduced during glacial lowstands of sea level (by up to $60 \mathrm{~km}$ ), and because of the dominantly longshore drift of the Canary Current, the potential impact of coastal upwelling fertility is highly unlikely at Site 958 . The same holds true for potential effects of upwelling near the $>400-\mathrm{km}$ distant Canary Islands. On the other hand, the distinct freshwater signal along with Heinrich meltwater Events 1, 2, and 3, which has been depicted by Wang et al. (1995) near $27^{\circ} \mathrm{N}$ and by Knaack (1997) offshore Cape Blanc near $21^{\circ} \mathrm{N}$, may have reached as far south as $24^{\circ} \mathrm{N}$. This assumption cannot yet be confirmed by paleosalinity reconstructions at Site 958 because of the extremely low resolution of our $\delta^{18} \mathrm{O}$ record (Fig. 2D), which is still being improved. However, the various massive shortterm and abrupt breakdowns in the summer SST record during the 
Figure 9. Variations in primary production (A) in Holes 958A (solid circles) and 958B (crosses), spliced, as compared with $(\mathbf{B})$ variations in parts per thousand $\delta^{13} \mathrm{C}$ (PDB) of the planktonic foraminifer G. ruber (var. white), indicating the nutrient content of the surface ocean. C. $\delta^{18} \mathrm{O}$ record of G. ruber (var. white) for stratigraphic reference. Paleoproductivity estimates are based on planktonic foraminifer counts (SIMMAX 28; Pflaumann et al., unpubl. data, and Sathyendranath et al., 1995).

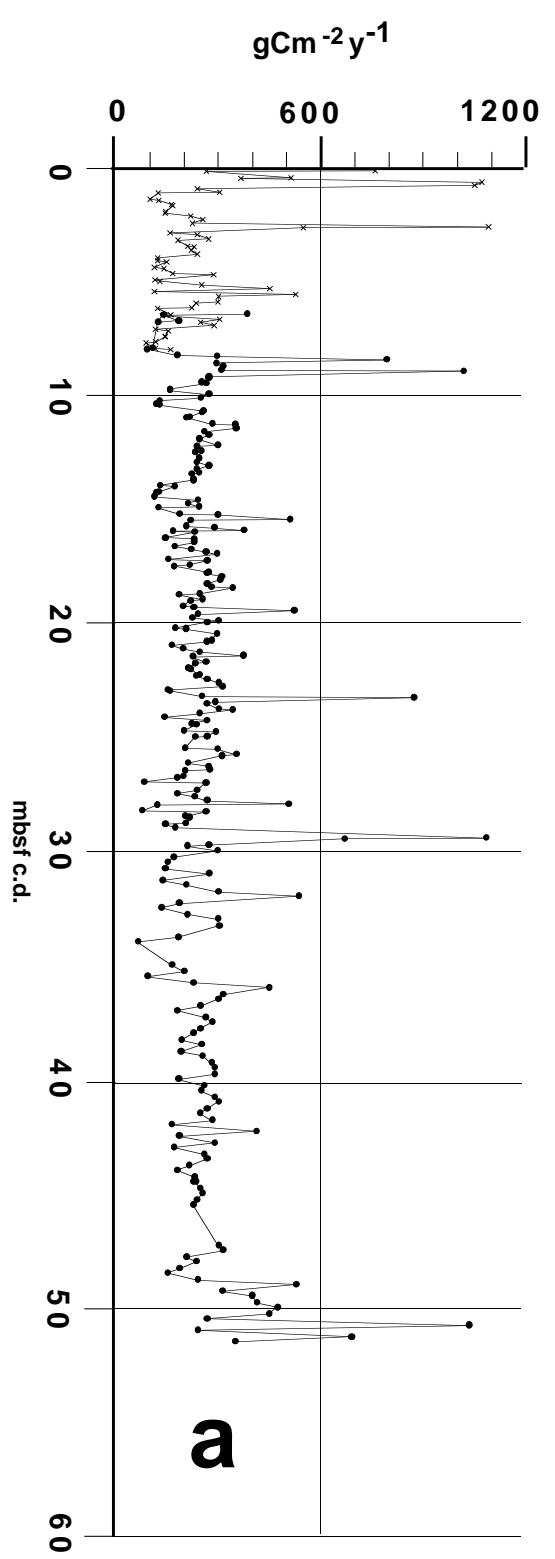

$\delta^{18} 0(\% \circ)$

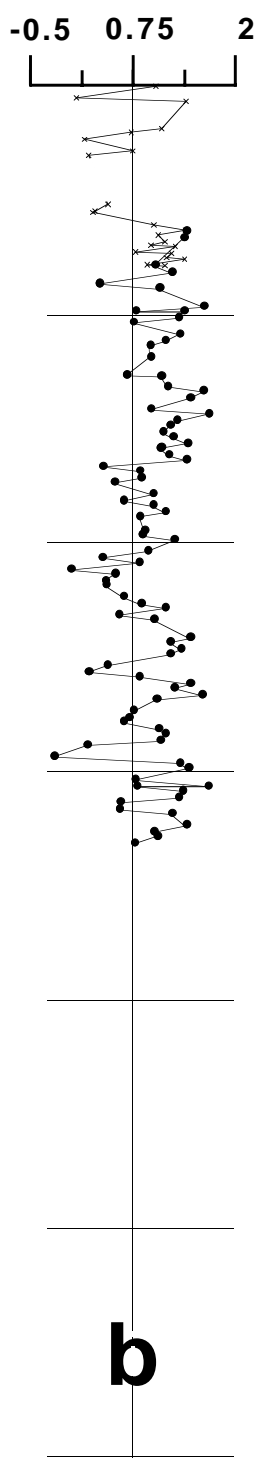

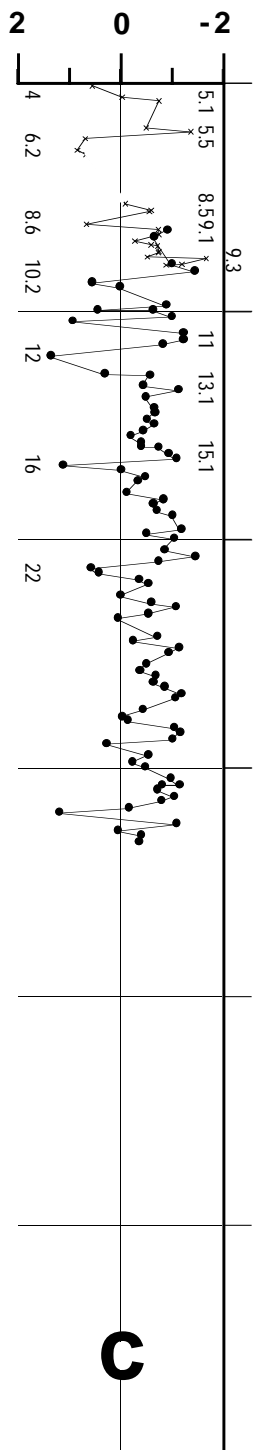

last 800 k.y. (Fig. 8), which differ clearly from the "usual" glacial-tointerglacial SST records observed in the subtropical North Atlantic (Crowley, 1981; Pflaumann, 1986, 1991), may support a similar type of climatic forcing, resulting from "Heinrich" events. Many of these events also match the paleoproductivity spikes (Fig. 9A).

The generally lower base level of paleoproductivity over the last 330 k.y. (Fig. 9) matches a higher level of winter SST during this time (Fig. 8) and hence, weaker dynamics of the Canary Current and trade winds. The lower productivity level also correlates with a clearly reduced fragmentation of foraminifers (Fig. 4E), indicating a weaker $\mathrm{CaCO}_{3}$ dissolution; however, the level of $\mathrm{CaCO}_{3}$ concentrations has also been reduced during this time (Fig. 2A; carbonate stratigraphy Unit 1), in contrast to our expectation.

\section{History of Eolian Dust Supply and Saharan Aridity}

The history of African aridity and subtropical wind systems, especially that of the trade winds and the midtropospheric African Easterly Jet (i.e., the Saharan Air Layer [SAL]), is deduced from variations in (1) magnetic susceptibility as a proxy of the iron-enriched, reddish dust flux from the lateritic South Sahara and Sahel zone (un- corrected for variations in pelagic sediment dilution), (2) the siliciclastic grain size distribution as a tracer of eolian dust or fluvial mud input (Fig. 11), hence of continental aridity and wind speed, and (3) clay minerals as a tracer of the differential dust sources, with illite and chlorite mainly originating in the Atlas Mountains and the northwestern Sahara and kaolinite originating in the South Sahara and Sahel zone (Lange, 1982; Sarnthein et al., 1982).

In the pelagic sediments at Site 958 we hardly expect any fluvial sediment input because of the distal site position and the lack of any potential major river mouth at the nearby Saharan coastline. Indeed, the generally well-sorted grain-size distribution of the silt fraction, where silt modal grain sizes increase with the proportion of silt $>6$ $\mu \mathrm{m}$, is characteristic of eolomarine dust deposits in the Atlantic and elsewhere (Field 1 in Fig. 11; Koopmann, 1981). Only occasional samples show a relative excess in clay $<6 \mu \mathrm{m}$ (Fig. 11; Field 2), which forms a clear signal of fluvial sediment discharge and humidity. These samples are confined to the section below $36 \mathrm{mcd}$ (i.e., to the time prior to $1.6 \mathrm{Ma}$.; Table 2) and, furthermore, to the rare (fluvial) turbidites in the middle and upper Pleistocene (Fig. 10B). In addition, some short-term extremes of the fraction $>6 \mu \mathrm{m}(70 \%-90 \%)$ mark most of the rare turbidite layers outlined in Table 1 . In a number 
Table 2. Names, midpoint ages of $\delta^{18} \mathrm{O}$ analog (sub-) stages, nannofossil and planktonic foram datums, and sedimentation rates at ODP Site 958.

\begin{tabular}{|c|c|c|c|c|}
\hline $\begin{array}{l}\text { Composite } \\
\text { depth } \\
\text { (mbsf) }\end{array}$ & $\begin{array}{l}\text { Midpoint } \\
\text { age } \\
\text { (ka) }\end{array}$ & $\begin{array}{c}\text { Stage/substage/nannofossil } \\
\text { and planktonic } \\
\text { foraminifer datums }\end{array}$ & $\begin{array}{l}\text { Sedimentation } \\
\text { rate } \\
(\mathrm{cm} / \mathrm{k} . \mathrm{y} .)\end{array}$ & References \\
\hline 0.10 & 65 & 4 & & $\delta^{18} \mathrm{O}$ stratigraphy \\
\hline 0.75 & 80 & 5.1 & 4.3 & $\delta^{18} \mathrm{O}$ stratigraphy \\
\hline 1.10 & 80 & LAD G. hexagonus & & This paper \\
\hline 2.05 & 120 & 5.5 & 3.25 & $\delta^{18} \mathrm{O}$ stratigraphy \\
\hline 2.90 & 160 & 6.4 & 2.1 & Carbonate stratigraphy \\
\hline 3.50 & 170 & 6.5 & 6.0 & Carbonate stratigraphy \\
\hline 4.80 & 225 & 7.4 & 2.4 & Carbonate stratigraphy \\
\hline 5.95 & 300 & 8.6 & 1.1 & $\delta^{18} \mathrm{O}$ stratigraphy \\
\hline 3.74 & 260 & (FAD E. huxleyi) & & Firth et al., 1996 \\
\hline 7.65 & 330 & 9.3 & 5.7 & $\delta^{18} \mathrm{O}$ stratigraphy \\
\hline 8.80 & 360 & 10 & 4.8 & Carbonate stratigraphy \\
\hline 12.00 & 440 & 12.2 & 4.0 & Carbonate stratigraphy \\
\hline 13.48 & 460 & LAD P. lacunosa & 2.4 & Firth et al., 1996 \\
\hline 12.50 & 465 & 12.4 & 2.0 & Carbonate stratigraphy \\
\hline 13.60 & 490 & 13.1 & 4.4 & Carbonate stratigraphy \\
\hline 14.65 & 525 & 13.3 & 3.0 & Carbonate stratigraphy \\
\hline 15.90 & 570 & 14 & 2.8 & Carbonate stratigraphy \\
\hline 16.40 & 600 & 15.3 & 1.7 & Carbonate stratigraphy \\
\hline 16.90 & 675 & 16.4 & 0.7 & Carbonate stratigraphy \\
\hline 17.20 & 695 & 17 & 1.5 & Carbonate stratigraphy \\
\hline 17.90 & 715 & 18.2 & 3.5 & Carbonate stratigraphy \\
\hline 18.10 & 765 & 18.4 & 0.4 & Carbonate stratigraphy \\
\hline 19.30 & 795 & 20 & 4.0 & Carbonate stratigraphy \\
\hline 20.00 & 822 & 21.1 & 2.6 & Carbonate stratigraphy \\
\hline 21.20 & 875 & 22.2 & 2.3 & Carbonate stratigraphy \\
\hline 21.80 & 900 & 23.1 & 2.4 & Carbonate stratigraphy \\
\hline 22.50 & 910 & 24 & 7.0 & Carbonate stratigraphy \\
\hline 23.40 & 970 & 26.2 & 1.5 & Carbonate stratigraphy \\
\hline 24.00 & 985 & 26.4 & 4.0 & Carbonate stratigraphy \\
\hline 24.30 & 995 & 27 & 3.0 & Carbonate stratigraphy \\
\hline 25.26 & 830 & (LAD R. asanoi) & & Firth et al., 1996 \\
\hline 34.38 & 1470 & LAD H. sellii & 2.05 & Firth et al., 1996 \\
\hline 35.44 & 1600 & (LAD C. macintyrei) & & Firth et al., 1996 \\
\hline 41.27 & 1950 & (LAD D. brouwer) & & Firth et al., 1996 \\
\hline 48.00 & 2000 & FAD G. truncatulinoides & 2.5 & This paper \\
\hline 49.47 & 2300 & (LAD G. miocenica) & & This paper \\
\hline 49.47 & 2410 & (LAD G. puncticulata) & & Firth et al., 1996 \\
\hline 51.04 & 2440 & (LAD D. pentaradiatus) & & Firth et al., 1996 \\
\hline 51.04 & 2610 & (LAD D. surculus) & & Firth et al., 1996 \\
\hline 51.04 & 2760 & LAD D. tamalis & 0.4 & Firth et al., 1996 \\
\hline 63.00 & 3770 & LAD R. pseudoumbilica & 1.2 & Firth et al., 1996 \\
\hline
\end{tabular}

of samples a relative deficit in clay reflects winnowing processes near the seafloor (Fig. 11; Field 3).

Based on the unique average increase in magnetic susceptibility near $31.5 \mathrm{mcd}$, we assume that the pronounced discharge of Saharan and Sahelian dust and, thus, a general increase in continental aridity, may have started about 1.2 Ma. (Fig. 10A). This date lags the general increase in grain sizes near 1.6 Ma. (Fig. 10B; $36.5 \mathrm{mcd}$ ), which is coeval with the cease of fluvial sediment input at Site 958 and a longterm increase in Sahelian dust-flux maxima identified at Site 659 near 1.5 Ma (Tiedemann et al., 1994). However, the general increase in Saharan dust discharge at Sites 658 and 659 had already started much earlier, about 2.7 Ma (Tiedemann et al., 1989; Tiedemann, 1991). On the other hand, the ages of 1.2-1.6 Ma clearly precede the general decreases in largely trade-wind-driven SSTs near $30 \mathrm{mcd}$ and, farther upcore, near $25 \mathrm{mcd}$ (0.8 Ma). Based on this different timing we conclude that the bulk supply of dust at Site 958 may be linked to a wind system different from the trades- the SAL, which is in harmony with modern and late Pleistocene findings (Sarnthein et al., 1982).

The short-term variations in the (markedly reddish) siliciclastic grain-size fraction $>6 \mu \mathrm{m}$ mirror many details of the $\delta^{18} \mathrm{O}$ record, with increased proportions of silt matching the cold stages (Fig. 10B and 10D). This record corroborates previous evidence (Sarnthein et al., 1982; Tiedemann et al., 1994), which suggests that both wind speeds over the east Atlantic and Saharan dust and aridity have markedly increased during Pleistocene glacial stages and reached a minimum during hypsithermal events. On the average, the coarse fraction $>6$ $\mu \mathrm{m}$ amounts to $20 \%-40 \%$, values that directly correspond to the local grain size range depicted on maps of glacial and interglacial eolomarine dust sediments (Koopmann, 1981; Sarnthein et al., 1982). Different from our expectation, the details of the high-resolution magnetic susceptibility record (Figs. 6, 10A) do not match the details of the grain-size record (Fig. 10B), which probably results from a differential input of iron minerals on different wind tracks.

The variations in dominant dust sources and wind tracks back to $\delta^{18} \mathrm{O}$ Stage 13 are documented by the illite/kaolinite ratio (Fig. 10C). High proportions of kaolinite (values of $0.22-0.35$ ) are an unequivocal tracer of Sahelian and South Saharan dust plumes (Lange, 1982) and match the cold extremes, which suggests that dust outbreaks from an arid Sahel zone via the SAL dominated the dust deposition at Site 958 during glacial times. The lateritic origin of dust from the Sahel is also reflected by the marked reddish stain. On the other hand, high portions of illite and chlorite (values of $0.35-0.47$ ) match the warm stages and document North Saharan dust sources and (longshore) trade-wind transport (Lange, 1982). In summary, during cold stages the ongoing trade-wind supply of illite was largely diluted by the massive supply of kaolinite dust from the South Sahara and Sahel, which followed an anticyclonic SAL-wind trajectory across the marginal east Atlantic to Site 958 (Sarnthein et al., 1982).

\section{CONCLUSIONS}

A detailed study of the changes in sediments, geochemistry, stable isotopes, and the faunal distribution at ODP Site 958 enabled us to uncover some basic trends in late Neogene stratigraphy and environmental history about $320 \mathrm{~km}$ to the west of northwest Africa over the last $2.8 \mathrm{~m} . \mathrm{y}$. (= $51 \mathrm{~m}$ core depth).

1. Based on the overlap of $\delta^{18} \mathrm{O}$ and $\delta^{13} \mathrm{C}$ records and curves of $\mathrm{CaCO}_{3}$ concentrations, we established a precise correlation between Holes 958A and 958B and a composite depth scale, with the main 
Figure 10. Volume magnetic-susceptibility (SI) record (A), percent siliciclastic grain-size fraction $>6$ $\mu \mathrm{m}(\mathbf{B})$, illite/kaolinite ratio in the clay fraction $<2$ $\mu \mathrm{m}(\mathbf{C})$, and $\delta^{18} \mathrm{O}$ record of $G$. ruber (var. white) for stratigraphic reference (D), plotted vs. depth in Holes 958A (solid circles) and 958B (crosses), spliced. Triangles show fluvial sediment input (based on Fig. $11)$; numbers are $\delta^{18} \mathrm{O}$ stages.

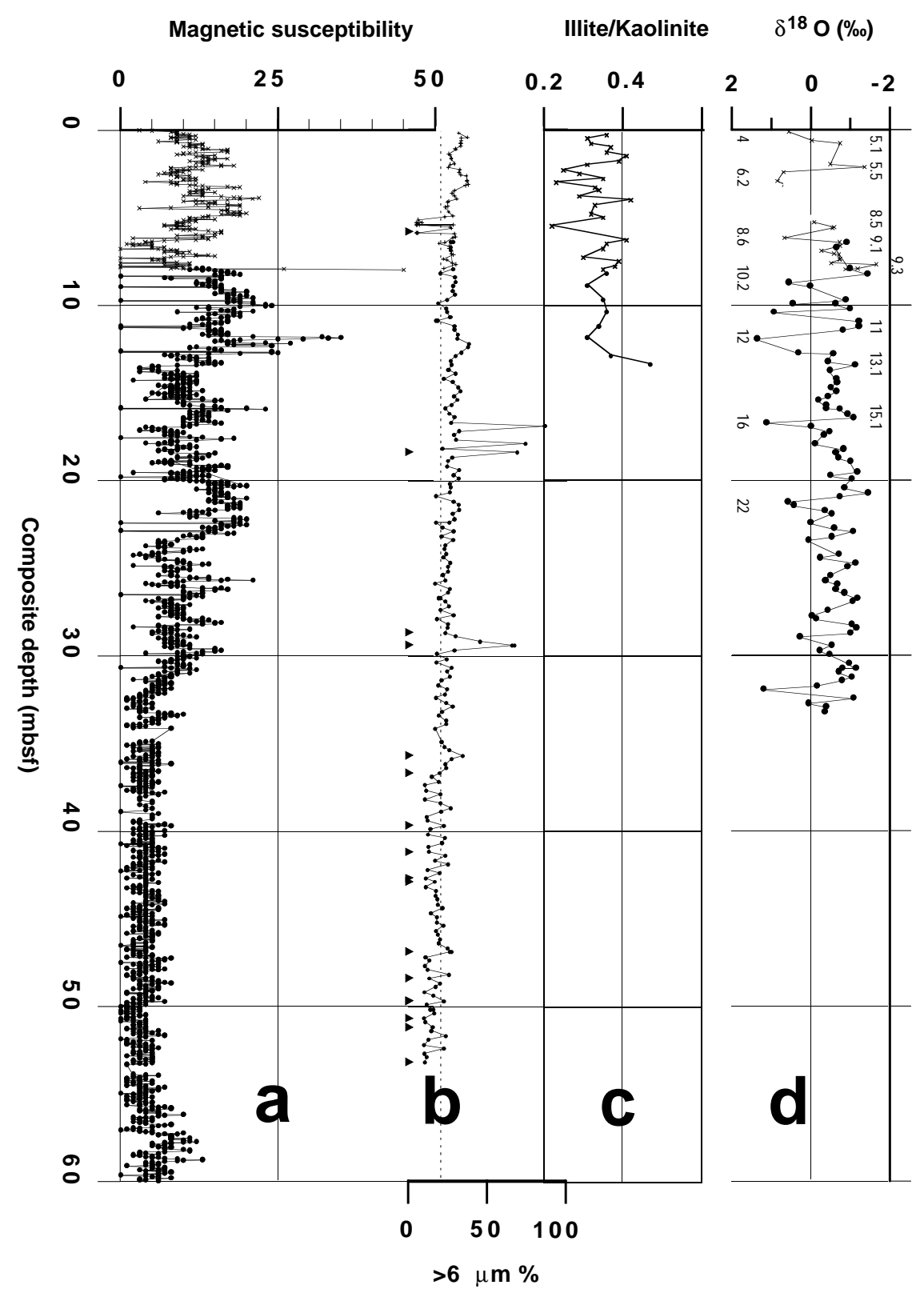

switch point at 6.37 mbsf in Hole 958B matching 0 mbsf in Hole 958A and $1.5 \mathrm{~m}$ of overlapping "good" core. This core splice is supported by the complete set of other records measured on the largely pelagic sediment section at Site 958.

2. A series of biostratigraphic datums and the stratigraphic correlation between the $\mathrm{CaCO}_{3}$ records of Site 958 and Site 659, which has been precisely dated by $\delta^{18} \mathrm{O}$ stratigraphy (Tiedemann et al., 1994), as well as a rough $\delta^{18} \mathrm{O}$ curve, enabled us to define a tentative chronostratigraphy with a time resolution on the scale of Milankovitch cycles over the last $1 \mathrm{~m} . \mathrm{y}$. and to identify the core-top age in Hole 958B near the top of $\delta^{18} \mathrm{O}$ Event 3.3.

3. Average sedimentation rates amount to $2.9 \mathrm{~m} / \mathrm{k}$.y. over the last $635 \mathrm{k} . \mathrm{y}$. and to 2.05 and $2.53 \mathrm{~cm} / \mathrm{k}$.y. back to the base of the Pleistocene (2.0 Ma), and decrease to about $0.4 \mathrm{~cm} / \mathrm{k}$.y. about $2.0-2.8 \mathrm{Ma}$, a sediment section with extensive hiatuses near 48-51 mbsf. Most of isotope Stage 16 has been lost because of turbidite erosion. In the total section, maxima in coarse fraction and benthic foraminifers reflect nine turbidite layers up to $53 \mathrm{~cm}$ thick.

4. High fragmentation rates of planktonic foraminifers correlate with low $\mathrm{CaCO}_{3}$ percentages, indicating increased dissolution during cold isotope stages. However, both concentrations of $\mathrm{CaCO}_{3}$ and fragmentation rates of foraminifers were clearly reduced during the last $260 \mathrm{k} . \mathrm{y}$.

5. Apart from frequent and prominent short-term fluctuations parallel to cold and warm climatic stages, the planktonic foraminifers show fairly low concentrations of cool and cold-water species over the last $330 \mathrm{k} . \mathrm{y}$., between about $760 \mathrm{ka}$ and $1.6 \mathrm{Ma}$, and prior to 2.4 $\mathrm{Ma}$, and a general increase in tropical-subtropical species during times prior to about Stage 19.

6 . The long-term evolution of sea-surface temperatures depicts a general decrease in SST during the late Pliocene, and low SST and a high seasonality of $6^{\circ} \mathrm{C} \sim 2.0-1.6 \mathrm{Ma}$. Subsequently, the range of summer and especially of winter SST increased; thus, the seasonality decreased until about $0.85 \mathrm{Ma}$. A reduced SST and increased seasonality range occurred until $\delta^{18} \mathrm{O}$ Event $8.3, \sim 0.26 \mathrm{Ma}$. Finally, SSTs were generally higher and seasonalities lower until $\delta^{18} \mathrm{O}$ Event 3.3 at the core top, about $50 \mathrm{ka}$.

7. Paleoproductivity shows a long-term decrease in the upper Pliocene, 2.8-2.3 Ma, a uniform level of low values averaging near a $300 \mathrm{~g} \mathrm{C} \mathrm{m}^{-2} \mathrm{yr}^{-1}$ until about $330 \mathrm{ka}$ and, subsequently a further gen- 


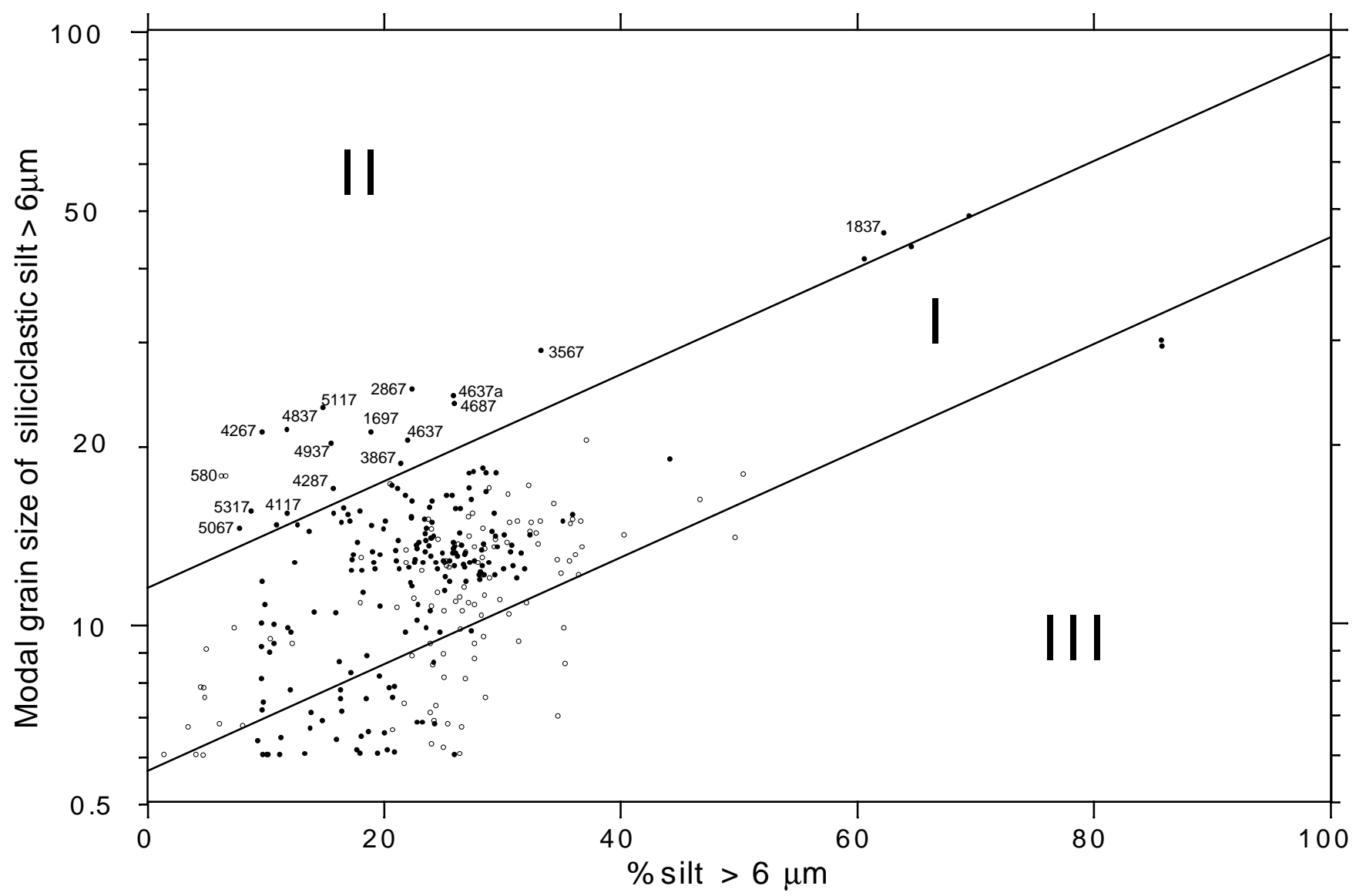

Figure 11. Winnowing (III), eolian (I), and fluvial (II) sources of hemipelagic siliciclastic sediments, separated by an empiric relationship between the percentage of silt $>6.3 \mu \mathrm{m}$ (abscissa) and the modal grain size of silt $>6.3 \mu \mathrm{m}$ (Koopmann, 1981; modified by Stein, 1985). Field I groups well-sorted samples, characteristic of eolian dust input. Field II groups samples with an excess in clay fraction $<6.3 \mu \mathrm{m}$ relative to silt-modal grain size, which is characteristic of riverine sediments. Field III groups samples with a relative deficit of clay fraction $<6.3 \mu \mathrm{m}$, indicative of winnowing near the seafloor. Upper line defined by $\mathrm{x}=27.5$, $\mathrm{y}$ $=20$ and $\mathrm{x}=71.0, \mathrm{y}=50$; lower line defined by $\mathrm{x}=27.5, \mathrm{y}=10$ and $\mathrm{x}=61.0, \mathrm{y}=20$. Samples from Hole 958A (solid circles) and 958B (open circles).

eral decrease to a base level of about $180 \mathrm{~g} \mathrm{C} \mathrm{m}^{-2} \mathrm{yr}^{-1}$, until $~ 50 \mathrm{ka}$. Based on this last decrease in productivity, which parallels a largely reduced seasonality of SST, we assume that the dynamics of the Canary Current and the forcing trade winds have been markedly attenuated as compared to preceding times. We surmise that a number of short-term extreme productivity spikes at Site 958, in the center of the Canary Current, may originate from the occasional Heinrich events, which led to a sudden advection of nutrient-enriched meltwater.

8. Based on a unique increase in siliciclastic grain sizes $>6 \mu \mathrm{m}$ and in magnetic susceptibility, we surmise that the (south) Saharan dust supply at $24^{\circ} \mathrm{N}$ and continental aridity increased significantly about 1.6-1.2 Ma. Subsequent to this time, the fluvial sediment supply ceased completely, except for some rare, thin turbidites. The variations in siliciclastic grain sizes and the illite-kaolinite ratio suggest that South Saharan dust discharge and aridity as well as wind speeds over the east Atlantic increased markedly during Pleistocene cold stages and reached a minimum during hypsithermal events.

\section{ACKNOWLEDGMENTS}

We gratefully acknowledge the great help of J. Baldauf and J. Firth, ODP, in selecting Site 958 and organizing the (fairly complicated) sample distribution. H. Erlenkeuser, University of Kiel, supervised with care the measuring of stable isotope data, and C. Samtleben provided supplementary nannofossil counts for the age calibration of the core top. G. Eglinton and J. Maxwell, University of Bristol, provided the lab facilities for biomarker analyses. The comments of three anonymous reviewers helped to improve on the quality of the manuscript. The Deutsche Forschungsgemeinschaft generously supported this study.

\section{REFERENCES}

Bé, A.W.H., and Tolderlund, D.S., 1971. Distribution and ecology of living planktonic foraminifera in surface waters of the Atlantic and Indian Oceans. In Funnel, B.M., and Riedel, W.R. (Eds.), The Micropaleontology of Oceans: Cambridge (Cambridge Univ. Press), 105-149.

Berggren, W.A., Hilgen, F.J., Langereis, C.G., Kent, D.V., Obradovich, J.D., Raffi, I., Raymo, M.E., and Shackleton, N.J., 1995. Late Neogene chronology: new perspectives in high-resolution stratigraphy. Geol. Soc. Am. Bull., 107:1272-1287.

Biscaye, P.E., 1965. Mineralogy and sedimentation of recent deep-sea clay in the Atlantic Ocean and adjacent seas and oceans. Geol. Soc. Amer. Bull., 76:803-832.

Bond, G.C., and Lotti, R., 1995. Iceberg discharges into the North Atlantic on millennial time scales during the last glaciation. Science, 276:10051010.

Chamley, H., 1989. Clay Sedimentology: Berlin (Springer-Verlag).

Cita, M.B., and Spezzibottiani, G., 1979. Late Neogene paleoenvironment studies on carbonate content, grain sizes, and dissolution, Cores 1-57 (DSDP Site 397). In von Rad, U., Ryan, W.B.F., et al. (Eds.), Init. Repts. 
DSDP, 47 (Pt. 1): Washington (U.S. Government Printing Office), 671682.

Crowley, T.J., 1981. Temperature and circulation changes in the eastern North Atlantic during the last 150,000 years: evidence from the planktonic foraminfieral record. Mar. Micropaleontol., 6:97-129.

Firth, J.V., et al., 1996. Proc. ODP, Init. Repts., 159T: College Station, TX (Ocean Drilling Program), 3-13.

Ganssen, G., 1981. Isotopic analysis of foraminifera shells: interference from chemical treatment. Palaeogeogr., Palaeoclimatol., Palaeoecol., 33:271276.

Jung, S., 1990. Zur Herkunft der Karbonate in Tiefseesedimenten des subtropischen und tropischen Ostatlantiks [M.sc. thesis]. Kiel Univ.

Kiefer, T., Abrantes, F., Sarnthein, M., Weinelt, M., and Labeyrie, L., 1995. Prominent productivity spikes in the subtropical North Atlantic parallel Heinrich meltwater spikes. ICP V Abstracts, Halifax, Nova Scotia, 85.

Kipp, N.G., 1976. New transfer function for estimating past sea-surface conditions from sea-bed distribution of planktonic foraminiferal assemblages in the north Atlantic. In Cline, R.M., and Hays, J.D. (Eds.), Investigation of Late Quaternary Paleoceanography and Paleoclimatology. Mem.Geol. Soc. Am., 145:3-41.

Knaack, J.J., 1997. Eine neue Transferfunktion zur Rekonstruktion der Paläoproduktivität aus Gemeinschaften mariner Diatomeen [Ph.D. thesis]. Kiel Univ.

Koopmann, B., 1981. Sedimentation von Saharastaub im subtropischen Atlantik während der letzten 25,000 Jahr. "Meteor" Forschungsergeb. Reihe C, 35:23-59

Lange, H., 1982. Distribution of chlorite and kaolinite in eastern Atlantic sediments off North Africa. Sedimentology, 29:427-432.

Mix, A.C., 1989. Productivity of the Pleistocene Atlantic ocean estimated from foraminiferal species: implications for paleo- $\mathrm{CO}_{2}$. Nature, 337:541-544.

Pflaumann, U., 1986. Sea-surface temperatures during the last 750,000 years in the eastern equatorial Atlantic: planktonic foraminiferal record of Meteor cores 13519, 13521, and 16415. "Meteor" Forschungsergeb. Reihe C., 40:137-161.

1991: Temperaturreaktionen des nordäquatorialen Atlantiks auf globale Klima-Anfachung während der letzten 750,000 Jahre. In: Frenzel, B. (Hrsg.) Klimageschichtliche Probleme der letzten 130,000 Jahre, Akademie der Wissenschaften und der Literatur, Mainz, Gustav Fischer Verlag, Stuttgart-New York, 177-196.

Pflaumann, U., Duprat, J., Pujol, C., and Labeyrie, L.D., 1996. SIMMAX: a modern analog technique to deduce Atlantic sea surface temperatures from planktonic foraminifera in deep-sea sediments. Paleoceanography, $11: 15-35$

Prell, W.L., and Curry, W.B., 1981. Faunal and isotopic indices of monsoonal upwelling: western Arabian Sea. Oceanol. Acta, 4:91-98.

Prell, W.L., Imbrie, J., Martinson, D.G., Morley, J.J., Pisias, N.G., Shackleton, N.J., and Streeter, H.F., 1986. Graphic correlation of oxygen isotope stratigraphy: application to the late Quaternary. Paleoceanography, $1: 137-162$.

Rosell-Melè, A., Eglinton, G., Pflaumann, U., and M. Sarnthein, 1995. Atlantic core-top calibration of the $\mathrm{U}^{\mathrm{k}}{ }_{37}$ index as sea-surface palaeotemperature indicator. Geochim. Cosmochim. Acta, 59:3099-3107

Ruddiman, W., Sarnthein, M., et al., 1989. Proc. ODP, Sci. Results, 108: College Station, TX (Ocean Drilling Program).
Ruddiman, W.F., Sarnthein, M., Backman, J., Baldauf, J.G., Curry, W., Dupont, L.M., Janecek, T., Pokras, E.M., Raymo, M.E., Stabell, B., Stein, R., Tiedemann, R., 1989. Late Miocene to Pleistocene evolution of climate in Africa and the low-latitude Atlantic: overview of Leg 108 results. In Ruddiman, W., Sarnthein, M., et al., 1989. Proc. ODP, Sci. Results, 108: College Station, TX (Ocean Drilling Program), 463-484.

Ruddiman, W., Sarnthein, M., Baldauf, J., et al., 1988. Proc. ODP, Init. Repts., 108 (Sections 1 and 2): College Station, TX (Ocean Drilling Program).

Sarnthein, M., Thiede, J., Pflaumann, U., Erlenkeuser, H., Fütterer, D., Koopmann, B., Lange, H., and Seibold, E., 1982. Atmospheric and oceanic circulation patterns off Northwest Africa during the past 25 million years. In von Rad, U., Hinz, K., Sarnthein, M., Seibold, E. (Eds.), Geology of the Northwest African Continental Margin: Berlin (Springer Verlag), 545-604.

Sarnthein, M., and Winn, K., 1990. Reconstruction of low and middle latitude export productivity, 30,000 years BP to Present: implications for global carbon reservoirs. In Schlesinger, S. (Ed.), Climate-Ocean Interaction: Dordrecht (Kluwer), 319-342.

Sathyendranath, S., Longhurst, A., Caverhill, C.M., and Platt, T., 1995. Regionally and seasonally differentiated primary production in the North Atlantic. Deep-Sea Res. 42:1773-1802.

Schemainda, R., Nehring, D., and Schulz, S., 1975. Ozeanologische Untersuchungen zum Produktionspotential der nordwestafrikanischen Wasserauftriebsregion 1970-1973. Geod. Geophys. Veröff., 16:3-84.

Stein, R., 1985. Rapid grain size analyses of clay and silt fraction by Sedigraph 5000D: comparison with Coulter Counter and Atterberg methods. J. Sediment. Petrol., 55:590-615.

Stein, R., and Sarnthein, M., 1984. Late Neogene oxygen-isotope stratigraphy and flux rates of terrigenous sediments at Hole 544B off Morocco. In Hinz, K., Winterer, E.L., et al., Init. Rpts. DSDP, 79: Washington (U.S. Govt. Printing Office), 385-394.

Tiedemann, R., 1991. Acht Millionen Jahre Klimageschichte von Nordwest Afrika und Paleaozeanographie des Angrenzenden Atlantiks: Hochaufosende Zeitreihen von ODP Sites 658-661 [Ph.D. thesis]. Geol.-Palaeont. Inst., Univ. Kiel, Ber. 46.

Tiedemann, R., Sarnthein, M., and Shackleton, N.J., 1994. Astronomic timescale for the Pliocene Atlantic $\delta^{18} \mathrm{O}$ and dust flux records of Ocean Drilling Program Site 659. Paleoceanography, 9:619-638.

Tiedemann, R., Sarnthein, M., and Stein, R., 1989. Climatic changes in the western Sahara: aeolo-marine sediment record of the last 8 million years (Sites 657-661). In Ruddiman, W., Sarnthein, M., et al., Proc. ODP, Sci. Results, 108: College Station, TX (Ocean Drilling Program), 241-277.

Wang, L., Sarnthein, M., Duplessy, J.-C., Erlenkeuser, H., Jung, S., and Pflaumann, U., 1995. Paleo sea surface salinities in the low-latitude Atlantic: the $\delta^{18} \mathrm{O}$ record of Globigerinoides ruber (white). Paleoceanography, 10:749-761.

Date of initial receipt: 4 November 1996

Date of acceptance: 16 May 1997

Ms 159TSR-061 